\title{
Cultural legitimacy and framing struggles in innovation journeys: A cultural-performative perspective and a case study of Dutch nuclear energy (1945-1986)
}

\author{
F.W. Geels ${ }^{\mathrm{a}, *}$, B. Verhees ${ }^{\mathrm{b}}$ \\ a SPRU, Science and Technology Policy Research, Freeman Building, University of Sussex, Brighton, BN1 9QE, UK \\ b School of Innovation Sciences, Eindhoven University of Technology, IPO 2.08, PO Box 513, 5600 MB Eindhoven, The Netherlands
}

\section{A R T I C L E I N F O}

\section{Article history:}

Received 13 April 2010

Received in revised form 28 October 2010

Accepted 15 December 2010

Available online 15 January 2011

\section{Keywords:}

Technical innovation journeys

Culture

Legitimacy

Framing

Nuclear energy

\begin{abstract}
A B S T R A C T
This article contributes to the field of innovation studies by addressing the role of cultural legitimacy in technical innovation journeys. The article develops a new perspective that connects insights from discourse theory, interpretive approaches to culture, cultural sociology and social movement theory. In contrast to functionalist and structuralist approaches (which tend to conceptualize culture in a top-down deterministic manner), our cultural-performative perspective emphasizes agency, collective sensemaking and framing struggles. Cultural change is a contested process, in which various groups perform on public stages to influence the attitudes and opinions of relevant audiences who provide financial resources, protection or support relevant for innovation journeys. We demonstrate the usefulness of this perspective with a longitudinal case study of nuclear energy in the Netherlands (1945-1986), which encompasses both the creation of legitimacy in the 1950s and 1960s, and its contestation by an anti-nuclear movement in the 1970s, which halted the innovation journey.
\end{abstract}

(c) 2011 Elsevier Inc. All rights reserved.

\section{Introduction}

New technologies not only need integration in relevant industries and markets, but also require societal embedding [1,2]. Deuten et al. [3] suggest that new technologies need to function in three environments (Fig. 1): a) the business environment, where technologies need to be integrated in relevant industries and markets, b) the regulation environment, where technologies need to match regulations, rules and standards, and c) wider society, where technologies need to be accepted by the wider public and fit with existing societal norms and beliefs. While the first environment refers to economic viability, the second and third environments refer to regulatory and cultural legitimacy.

Many definitions of legitimacy exist (see Johnson et al. [4] for an in-depth discussion). For our definition, we build on Scott [5], who makes a distinction between regulatory, normative and cognitive legitimacy. Because normative and cognitive legitimacy both refer to the 'wider society' in Fig. 1, we propose one term, 'cultural legitimacy', to encompass both dimensions. This fits well with Suchman's [6] well-known definition of legitimacy as: “(...) a generalized perception or assumption that the actions of an entity are desirable, proper or appropriate within some socially constructed system of norms, values, beliefs and definitions". 1

The development and societal embedding of new technologies require the alignment of all three environments in Fig. 1. We use the term 'innovation journey' [7] to represent the open, uncertain and non-linear nature of this alignment process. The 'journey' aspect also highlights the agency dimension, with actors navigating, negotiating, and struggling as they go along.

\footnotetext{
* Corresponding author.

E-mail addresses: f.w.geels@sussex.ac.uk (F.W. Geels), b.verhees@tue.nl (B. Verhees).

1 While norms and values relate to normative legitimacy, beliefs and definitions relate to cognitive legitimacy.
} 


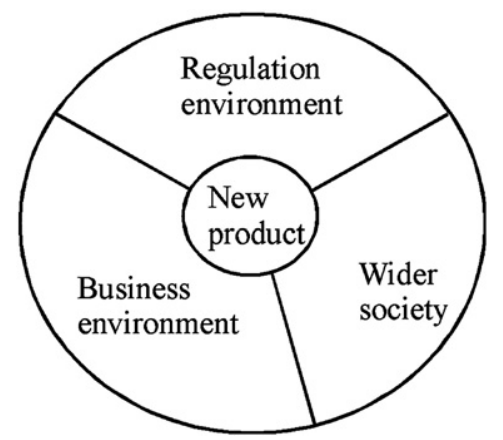

Fig. 1. Relevant environments for new products [3].

Most approaches in the field of innovation studies deal with the business dimension of innovation journeys, sometimes complemented with regulatory dimensions (e.g. the systems of innovation approach). Innovation studies scholars tend to pay less attention to cultural legitimacy and the wider public, although there is some emerging interest. Jacobsson and Lauber [8] for instance, relate the diffusion of solar cells and wind turbines in Germany to "an exceptionally high degree of legitimacy of renewable energy sources in German society", which emerged from public concerns about climate change and positive visions of renewables. In a similar vein, Geels et al. [2] showed that interactions between cultural enthusiasm and concern about side-effects explained the ups and downs of various generations of psychotropic drugs. On a general level, Lovell [9] showed that a shared discourse provided direction for innovation journeys in low energy housing and aligned supportive 'discourse coalitions'. Bergek et al. [10], who introduced legitimation in the technological innovation systems approach, distinguish two relevant mechanisms: a) the articulation of positive expectations around new technologies, which relates to cultural framing, and b) the accumulation of actors that enhances the power of advocacy coalitions, which relates to attempted changes in the regulatory framework. Despite these interesting contributions, it is fair to say that the field of innovation studies has paid limited attention to the role of culture and wider society. This article's general contribution is to help fill that gap.

While the above contributions establish the influence of cultural legitimacy on innovation journeys and propose visions, expectations and discourses as important variables, more can be done to unpack the causal mechanisms through which these variables produce cultural legitimacy. This article's more specific contribution therefore is to improve the understanding of the production of cultural legitimacy via discourse and framing struggles.

The (strategic management) literature (and the above contributions) already offers useful insights about the effects of cultural legitimacy on innovation journeys because of positive influences on the provision of resources from investors and venture capitalists, political protection from policy makers, and support from the wider public [11-14]. In the early phases of innovation journeys, new technologies have low legitimacy, because they suffer from the 'liability of newness' [15] and are perceived as strange, weird, or unfamiliar. The creation of cultural legitimacy is therefore important in the early phases of innovation journeys:

“(.) legitimacy is crucial in the early years of a new venture's existence, even before it begins to generate profit” [16].

"As is widely acknowledged in previous research, legitimacy is a prerequisite for the formation of new industries" [10].

Because early innovation journeys are characterized by uncertainty (about market demand, user requirements, technical performance, price), it is difficult to underpin investment decisions with reliable cost-benefit calculations. Instead, legitimacy plays a crucial role in early investments, ventures and policy programs:

"But new ventures need resources from their environment, and, in the end, the motivating factor for external actors to give such resources is their belief or feeling that the venture is indeed competent, efficient, effective, worthy, appropriate, and/or needed. (...) Legitimacy provides a basis for decision-making that is different from means-ends rationality" [16].

So, the literature already offers insights about important effects of cultural legitimacy in the early phases of innovation journeys (by stimulating the provision of investments, support and acceptance). Cultural legitimacy is also important for later phases of innovation journeys, because it helps to maintain the political and public support for established technologies. Scholars have found that the loss of legitimacy ('delegitimation') weakens this support and may contribute to the decline of existing technologies and industries $[17,18]$.

While the literature recognizes the effects of cultural legitimacy, less is known about the creation of legitimacy. Building on Suchman's definition of legitimacy, Johnson et al. [4] usefully suggest that legitimacy arises when actors "construe an innovation as consonant with and linked to the existing widely accepted cultural framework of beliefs, values and norms". Because Johnson et al. [4] do not elaborate on this process of construing and linking, we will build on their basic suggestion and develop further insights. Against this background, the paper addresses the following research question: how is cultural legitimacy created (and maintained or lost) during technical innovation journeys? 
We answer this question in two ways. First, we develop a new perspective that combines the notion of innovation journey with insights from two bodies of literature: a) insights from cultural sociology and discourse theory [19-21] about the production of legitimacy via framing and discourse, b) insights from social movement theory [13,22] to emphasize the performative and interactive dimensions of framing struggles. This perspective not only aims to show that culture is important, but also articulates the mechanisms through which cultural legitimacy is created during innovation journeys.

Second, we investigate the usefulness of this perspective by applying it to an historical case study: the ups and downs of nuclear energy in the Netherlands (1945-1988). We selected the example because it is an 'extreme case', which is "well-suited for getting a point across in an especially dramatic way, which often occurs for well-known case studies" [23]. The case is extreme, because cultural legitimacy was very high in the 1950s and 1960s, leading to plans that envisaged that 50\% of electricity production would be nuclear, the opening of the first Dutch nuclear reactor in 1969, and the second one in 1973 (Fig. 2). But intense and public contestation in the 1970s and 1980s undermined nuclear power's cultural legitimacy. The implementation of nuclear expansion plans was halted after the 1986 Chernobyl disaster, which caused the relative contribution of nuclear power to electricity generation to decline (Fig. 2).

The conceptual framework should be able to explain this extreme case, and give a more sophisticated explanation than the above account, which places the explanatory burden primarily on the Chernobyl disaster. While Chernobyl was, of course, important, it does not provide sufficient explanation because the disaster did not have the same effects in other countries. In France, for instance, Chernobyl had little influence, because it was interpreted as an indication of the unsafe nature of Russian reactor designs. The disaster therefore had no significance for 'superior' French technology [24]. Our analysis should therefore show that the Dutch interpretation of Chernobyl was influenced by specific discursive struggles between opponents and proponents that accompanied the nuclear innovation journey.

The article is structured as follows. Section 2 develops our new perspective. Section 3 discusses methodology and data sources. Section 4 presents the case study. Section 5 analyzes the case. The paper ends with conclusions and discussion in Section 6.

\section{Framing struggles, cultural legitimacy and innovation journeys}

\subsection{Production of cultural legitimacy}

The cultural legitimacy of actions, innovations or ventures arises from the creation of linkages to the existing cultural framework [4]. Because 'culture' is a diffuse concept with multiple meanings, there are different views on how this 'linking' happens. We briefly present a stylized representation of four views, as a stepping stone towards articulating our position.

Firstly, in a functionalist view, culture is a separate domain that provides ultimate ends and values [25]. Culture shapes action by defining what people want (Fig. 3). Legitimacy arises from conformity to existing norms. Because people are socialized into existing values, there is little space for agency, freedom and creativity. Functionalism has therefore been criticized for reducing people to 'cultural dopes'.

Secondly, in a structuralist view, culture is a cognitive deep structure that constitutes people's perception of reality and provides the frames of meaning within which people act [26]. Legitimate action arises from conformity to these deep structures. Because culture operates 'behind the backs of actors', this view tends towards cultural determinism, with little attention for agency (Fig. 4).

Thirdly, interpretive approaches to culture developed a more active view, focusing on agency and the creation of meaning. Meaning is seen to arise from interpretation, which is an active process in which actors draw upon cognitive deep structures (Fig. 5). Culture thus becomes a 'toolkit': actors draw upon cognitive deep structures or 'repertoires' and actively use symbols and categories for sensemaking [19]. Interpretive approaches do not see culture as coherent and monolithic, but as a fragmented and (sometimes) contradictory set of repertoires that actors can mobilize in different ways.

Fourthly, discourse theory adds sociological dimensions by focusing on collective meanings and sense-making around specific issues (e.g. particular technologies, problems, industries). Hajer [20] defines 'discourse' as: “a specific ensemble of ideas, concepts and categorizations that are produced, reproduced, and transformed in a particular set of practices, and through which meaning is given to physical and social realities". Collective sensemaking is seen as an ongoing process that involves multiple actors interacting

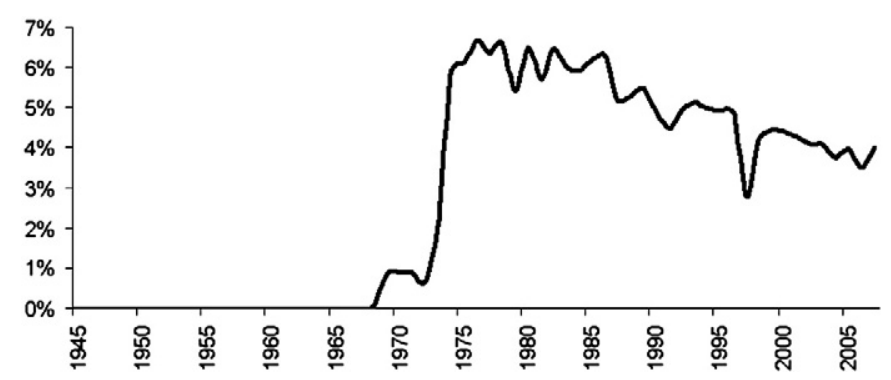

Fig. 2. Nuclear share in Dutch electricity generation from 1945 to 2007 (Central Bureau of Statistics; www.cbs.nl). 


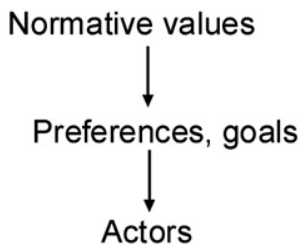

Fig. 3. Functionalist view of culture.

and debating over issues. Meanings that have been produced do not go away, but provide the background material for the next round of collective 'sensemaking processes'. Sequential rounds of sense-making thus lead to discourses, i.e. particular ways of talking and thinking about an issue (Fig. 6).

Building on the discursive view, we suggest that the cultural legitimacy of technologies derives from the content and meaning of discourses, which depend on the way that deep-structural elements, concepts, ideas, metaphors, arguments and images are ordered and related. For innovation journeys, actors aim to produce legitimacy by articulating positive discourses around new technologies. We discuss the relevant mechanisms in the next section.

\subsection{Framing struggles, legitimacy and innovation journeys}

The interpretive and discursive views, discussed above, make cultural change more endogenous, in contrast with the functionalist and structuralist approaches that treat cultural change as exogenous development that happens 'behind the back' of actors. But discursive approaches are sometimes criticized for focusing too much on 'talk', with too little connection to economic and political action [27]. We therefore propose two additions that, firstly, link discourses to cultural performances which aim to influence relevant actors and, secondly, link discourses to contestation and framing struggles.

Regarding the first addition we propose that cultural actions are performed on certain stages to influence certain audiences. Using the performative approach to cultural studies $[28,29]$ we can elaborate the notion that legitimacy is, by definition, oriented towards other actors who need to be convinced that something is appropriate, right or desirable. Cultural action is therefore not only about sense-making by focal actors (as some discursive approaches suggest), but also about influencing attitudes, feelings, and opinions of other relevant actors on which focal actors are dependent, e.g. for the provision of financial resources, protection or support [11,12]. Through cultural actions, focal actors try to achieve a favorable attitude, opinion or response from investors, venture capitalists, policy makers, and the wider public. This implies that cultural action in the performative approach is not only about 'talk', but also about the effects of discourses and legitimacy on politics (e.g. protection, support) and economics (resource provision, investments). As Suchman [6] argues:

\section{“(...) audiences are most likely to supply resources to organizations that appear desirable, proper or appropriate” [6].}

Because legitimacy entails an element of moral evaluation, the performative approach also reintroduces values and normative dimensions into the conceptualization of culture (Fig. 7). The performative approach further emphasizes that collective sense making takes place on public stages (e.g. public debates, media, newspapers). Social movements, industry associations, policy makers, and special-interest groups perform on these public stages, and engage in discursive struggles that aim to influence collective discourses.

The second addition is that cultural change is a contested process, in which various social groups struggle to influence evolving discourses. Building on cultural sociology $[19,21]$ we propose that various groups frame technologies in particular ways, and that these frames compete on public stages to influence the general discourse. Frames vary in plausibility and salience (see below), and in flexibility and inclusivity. Focused and exclusive frames revolve around one specific theme or issue and only resonate with a specific group. Frames that incorporate more issues and are articulated in such a way that they resonate with larger audiences, may evolve into master frames:

"Some collective action frames are quite broad in terms of scope, function as a kind of master algorithm that colors and constrains the orientations and activities of other movements. We have referred to such generic frames as "master frames" in contrast to more common movement-specific collective action frames that may be derivative from master frames" [22].

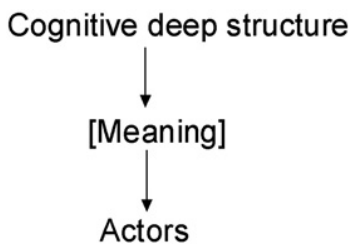

Fig. 4. Structuralist view of culture. 


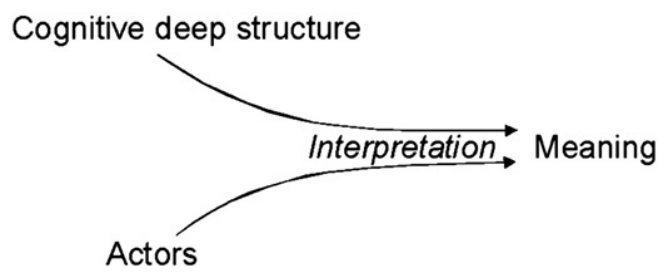

Fig. 5. Interpretive approach to culture.

We refer to these master frames as 'discourses', because they are more general, contain various specific framings and appeal to a wider audience. We thus propose a distinction between: a) discourses, which are shared, sedimented, more general ways of thinking and talking about technologies (e.g. the anti-nuclear discourse), and b) frames and framing struggles, which focus more specifically on the meaning and interpretation of specific issues (e.g. radiation effects of nuclear energy, nuclear waste problems, explosion dangers).

We see the interaction between general discourses and specific frames as recursive. Existing discourses enable and constrain how actors can frame specific issues, but framing struggles can also influence broader discourses if particular frames become salient and influence broader ways of talking and thinking; certain elements of frames may thus find their way into discourses. Rip and Talma [30] argue that discourses in modernist societies typically evolve into an antagonistic dichotomy between 'for' and 'against':

"Neither proponents nor opponents are simple categories, but to think in those terms seems natural. And the labels are used prospectively: introductors of new technology now expect that there may be contestation and watch out for opponents. The opponent/proponent dichotomy has become a pattern in our culture, and it serves actors in their attempts to order a complex environment. In that sense, the dichotomy is now a fact of life" [30].

Interactions between 'pro' and 'contra' discourses typically occur around specific issues or events, which form the concrete battlegrounds where opponents and proponents engage in framing struggles. In these struggles actors develop and adjust frames and counter-frames in response to each other and to deep-structural repertoires (which tend to change only slowly). Cultural struggles in innovation journeys are thus played out as 'technological dramas' on the public stage [31] with actors aiming to influence the perceptions of relevant 'audiences' (who provide resources, support, acceptance etc.). Product-champions usually articulate promises, expectations, and visions as to how particular innovations will solve particular problems and transform the world at large [32,33]. Opposition groups, in contrast, tend to highlight disadvantages, risks, and negative side-effects.

Using insights from social movement theory, we can further operationalize relevant mechanisms in framing struggles between dominant discourses (often articulated by technical and political elites) and emerging discourses (often articulated by relative outsiders and social movements). Because social movements start as outsiders to existing orders, they tend to use noninstitutionalized action (protest marches, blockades, leaflets, and petitions) to exert pressure. The mobilization of resources (money, members, expertise, and relations) is one mechanism that enhances the power and influence of social movements [34]. But social movements also exert pressure through cultural framing, which influences the cognitive space in which issues are debated [35]. Social movements contest the dominant discourse by engaging in framing struggles over specific issues. The plausibility and salience of specific frames depends on positive scores the following dimensions $[22]^{2}$ :

1. Actor credibility: the status or perceived expertise of the social groups advocating particular frames.

2. Empirical fit: the perceived correspondence between the frame and real-world events (the more 'evidence' a frame/discourse can claim, the higher its empirical fit).

3. Centrality: the perceived importance of the topic or debate to particular audiences (relative to other topics or debates).

4. Experiential commensurability: the resonance between the frame and the everyday experiences of audiences (if frames are very abstract and have little bearing on people's daily life, experiential commensurability is low).

5. Macro-cultural resonance: the fit between frames and cultural repertoires (deep structures).

Frames that score higher on these dimensions are stronger and may influence broader discourses, which in turn influence the legitimacy of innovations and the attitudes of external actors who provide resources, support and protection. While positive frames and discourses stimulate innovation journeys, negative frames and discourses may discredit, undermine or even halt them.

\section{Methodology and data sources}

We investigate the usefulness of our conceptual additions (cultural performances, framing struggles, and the evolving scores on the five dimensions for plausibility and salience) by applying it to an historical case study. We adopt a case study

\footnotetext{
${ }^{2}$ We combine Benford \& Snow's concept of 'credibility of articulators' with 'frame consistency' (the degree to which there is a perceived contradiction between what the articulator says and does), because the empirical difference of both concepts is not clear and their effect is similar.
} 


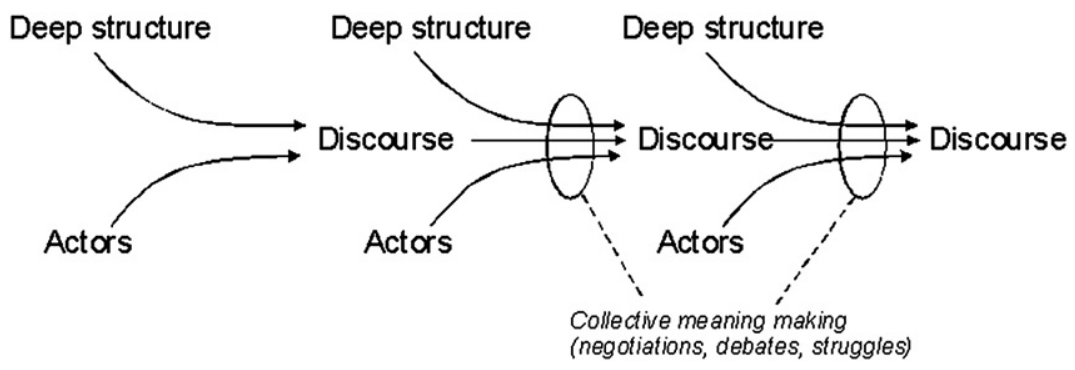

Fig. 6. Discursive approach to culture.

methodology, because case studies are well suited for exploratory research, rich in context and enabling for tracing of processes and causal mechanism [36]. The latter is necessary because our perspective practices a mechanism-oriented style of theorizing. This kind of theory is not oriented towards general laws or correlations between dependent and independent variables, but instead aims to uncover the social mechanisms that underlie certain processes [37,38]; in our case the mechanisms that link cultural dynamics to innovation journeys. Case studies are more suited for this kind of research than cross-sectional, statistical or time-series analyses.

We have chosen a historical case, Dutch nuclear energy developments between 1945 and 1986, because this enables us to study longitudinal processes of innovation journeys, cultural legitimacy and framing struggles. We have divided the case study into two periods. For the first period (1945-1970) we will analyze how product champions established legitimacy for the new technology, which was initially associated with death and danger because of the use of atom bombs during the Second World War. For the second period (1970-1986), we will analyze how this legitimacy was contested by 'outsiders' who gradually coalesced into a social movement against nuclear energy. We will study the struggles by analyzing how the cultural actions of groups played on the five dimensions that shape the salience of cultural discourses.

Although the case study focuses on cultural performances and framing struggles, we do not advocate cultural determinism. Other dimensions such as the technology, the business environment, and the regulatory environment were also important for the innovation journey of nuclear energy. But the case study focuses only on the cultural logics and mechanisms, because we want to investigate how cultural legitimacy and framing struggles influence innovation journeys.

The case study is based on multiple data-sources, which allows for triangulation [36]. We use secondary sources such as academic histories of nuclear energy. We also use somewhat unconventional primary sources, such as newspapers, antinuclear movement brochures, pro-nuclear educational material, popular-scientific books, news clips and documentaries. In these sources we not only focused on arguments in verbal discussions and debates, but also on cartoons, advertisements, slide shows, book covers and posters, because these are important ways through which actors convey meaning. Additionally we incorporate cultural actions such as protest marches and petitions. We have also done a few interviews with relevant stakeholders to check our interpretation of the case and fill in some gaps. Semi-open interviews were done with: Professor Leo Jansen (Member of Steering Group of the Broad Societal Discussion (BSD) on Energy Policy, 1981-1984), Jan Willem Storm van Leeuwen (Senior consultant at the Center for Energy Conservation and Sustainable Technology and co-author of scenarios used in the BSD), Dirk Bannink (anti-nuclear activist and member of the action group Break the Atomic Chain Netherlands, 1977-1982).

The analysis focuses on public debate as an important stage for the cultural struggle [39]. Our analysis has a qualitative part and a quantitative part. The case study in Section 4 makes an in-depth qualitative analysis of public performances, framing, meaning, images, metaphors, and symbols. We also made a quantitative newspaper analysis for two reasons: 1 ) it serves as a first

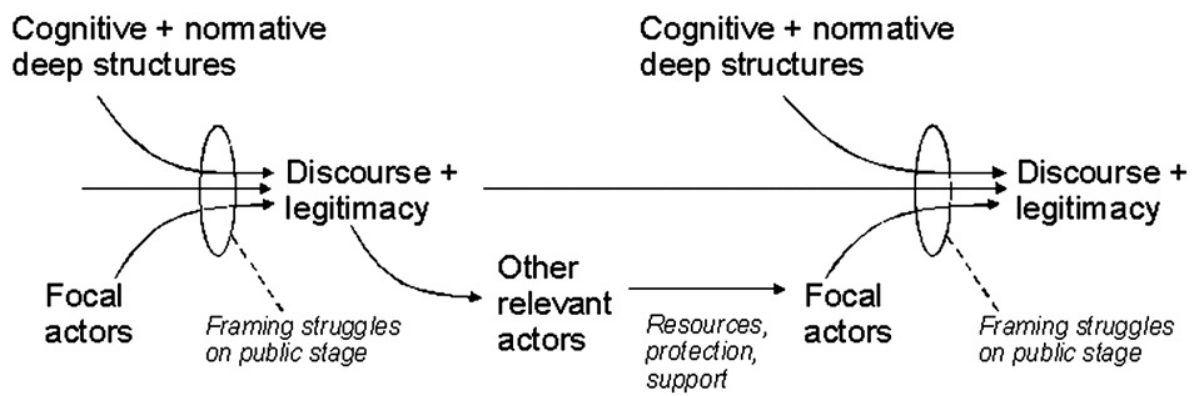

Fig. 7. Performative view on cultural action. 


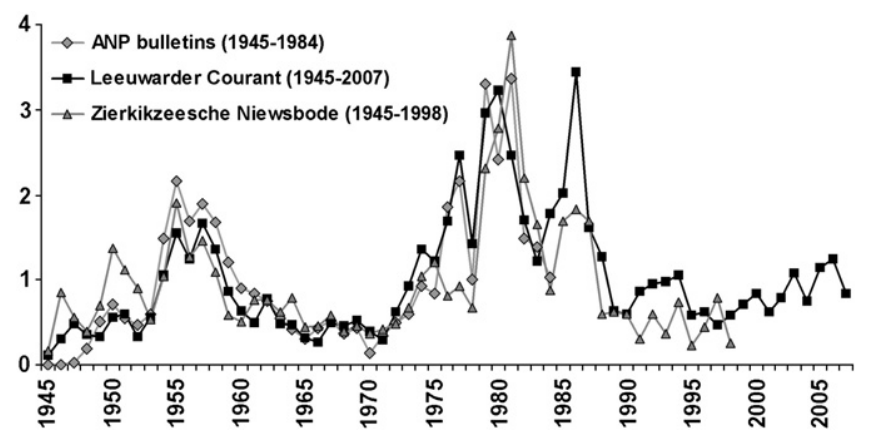

Fig. 8. Quantitative analysis of media attention for nuclear energy.

approximation of public attention for nuclear power, and provides an indication of 'centrality', i.e. the perceived importance of nuclear energy in the public sphere, 2) it provides further legitimation for dividing our case study into two periods. While newspaper counts are only a rough indicator of public attention, it is the best one available for the investigation of specific issues over long time-scales, as Newig [40] argues:

"Assuming that in today's democracies the mass media constitute by far the most important vehicle for shared attention and political communication, media coverage, then, should best reflect public attention."

For this quantitative analysis, we used two daily regional newspapers that offer a sufficiently longitudinal online database: The Leeuwarder Courant and the Zierikzeesche Nieuwsbode. ${ }^{3}$ Additionally, we used a digital archive database of transcripts of radio bulletins by the Dutch national news agency ANP for the period 1945-1984 (http://anp.kb.nl/). The digital archives were searched for all articles containing the following keywords: atoomenergie, atoomkracht, atoomcentrale, kernenergie, kerncentrale. $^{4}$ This produced 9536 unique records in the Leeuwarder Courant (1945-2007), 2192 unique records in the Zierikzeesche Nieuwsbode (1945-1998), and 5838 unique records in the ANP radio bulletin (1945-1984). These records, which contained news articles, opinion pieces, correspondence columns and official announcements, were counted on a peryear basis and the result is plotted in Fig. 8. To facilitate visual comparison between these datasets, we normalized the time series so that for each set, the value "1" corresponds to its average number of articles per year (calculated over the entire period).

The results show an interesting pattern with two distinct curves, the first reaching a maximum around 1957, when the government published its most ambitious expansion plans, and the second around 1980, when large anti-nuclear protest marches took place. The Chernobyl accident, which produced a spike of attention in 1986, was followed by decreasing attention until the early 2000s when nuclear energy became increasingly framed as possible solution to climate change.

We now turn to a qualitative investigation of cultural actions for the first period (1945-1970), when legitimacy was created through positive discourses, and for the second period (1970-1986), when cultural legitimacy was contested by the anti-nuclear movement. The second period receives somewhat more attention than the first period, because of our interest in framing struggles between opponents and proponents. Our case study makes a narrative analysis, because this can capture fuzzy, unfolding processes [41]. Some narratives, however, only describe 'one damn thing after another'. To turn case histories into case studies, narrative plots should be used to provide more analytical focus [42]. These plots allow scholars to write analytic chronologies, not just case histories. While analytic chronologies also lay out the narrative, "there is an explicit attempt to interpret and explain" the process [43]. The aim is not to 'tell the story as it really was', but to use narrative plots that provide more selective analytical focus. We use the five dimensions of discourse plausibility and salience as the narrative plot. For both periods, we first set the scene, and then analyze the case with the five dimensions. Although we maintained chronology as much as possible, the case structuring through analytical dimensions sometimes precluded this. Furthermore, some analytical dimensions may appear twice in the story if the empirical events are substantially separated in time.

\footnotetext{
${ }^{3}$ No national dailies currently offer digital searchability over the desired timeframe. The Leeuwarder Courant is the oldest Dutch newspaper still operating under its original name and the 10th largest regional newspaper (http://www.archiefleeuwardercourant.nl/.) Although The Zierikzeesche Nieuwsbode is smaller, it is interesting, because the Borssele nuclear power plant is located in the province it caters to (http://zoeken.krantenbankzeeland.nl/).

4 Plural forms (i.e. 'kerncentrales') and compound words (e.g. 'kerncentralestoring') were included through the use of wildcard operators.
} 


\section{Case study: the ups and downs of Dutch nuclear energy (1945-1986)}

\subsection{The Atomic Age and the creation of cultural legitimacy (1945-1970)}

After WWII, nuclear technology was linked to the atom bomb and death. Although military considerations were upfront in other countries, Dutch researchers convinced policy makers to focus on civilian applications. In 1946, the government therefore established the Foundation for Fundamental Research of Matter (FOM) and set up a joint venture with Norway (1950) to develop a research reactor in Kjeller [44] to gain experience for construction of a domestic reactor and the build-up of a Dutch nuclear industry. In 1951, American researchers demonstrated that nuclear energy could be used for electricity production [45]. While in the USA the first practical exploitation remained within the military domain (nuclear submarines), thoughts also turned to the civilian domain. Dutch authorities wanted to join this domestic development of nuclear energy, as the following newspaper quote suggests:

"When we find that a gram of uranium equals 25 tons of carbon as an energy source, when we remember that England hopes to have a ship powered by atomic energy in 1954, and that the US mean to equip a submarine with atomic energy and plans are being executed for the atomic propulsion of bombers, then it speaks for itself that a forward-looking people cannot remain on the sidelines of the research into atomic energy" [46].

Eisenhower further articulated this vision in his 'Atoms for Peace' speech in 1953, promising that America would lift some of the secrecy concerning nuclear technology and relax its ban on the export of enriched uranium.

The civilian development of this new technology required the creation of cultural legitimacy. The main challenge was to develop frames and discourses that removed the negative associations between nuclear energy and the atom bomb. Nuclear technology advocates therefore began to articulate positive visions about nuclear energy. The mid-1950s thus experienced increased cultural actions, performances in public media and the articulation of pro-nuclear discourses. The core message is succinctly conveyed by Walt Disney's children's book 'Our Friend the Atom' (translated and published in The Netherlands in 1959, [47]), in which the promise of the atom is a genie, ready to grant humanity's wishes in the domains of energy, food, health and peace (Fig. 9).

\subsubsection{Macro-cultural resonance}

Modernization, technical progress and industrialization were important macro-repertoires in the 1940s and 1950s. Nuclear proponents linked their frames to these repertoires to enhance the 'macro-cultural resonance'. Fig. 10 shows excerpts from two slideshows ("Blessings of the Atom" [48] and "Man and the Atom" [49]) which the US Information Service provided to the

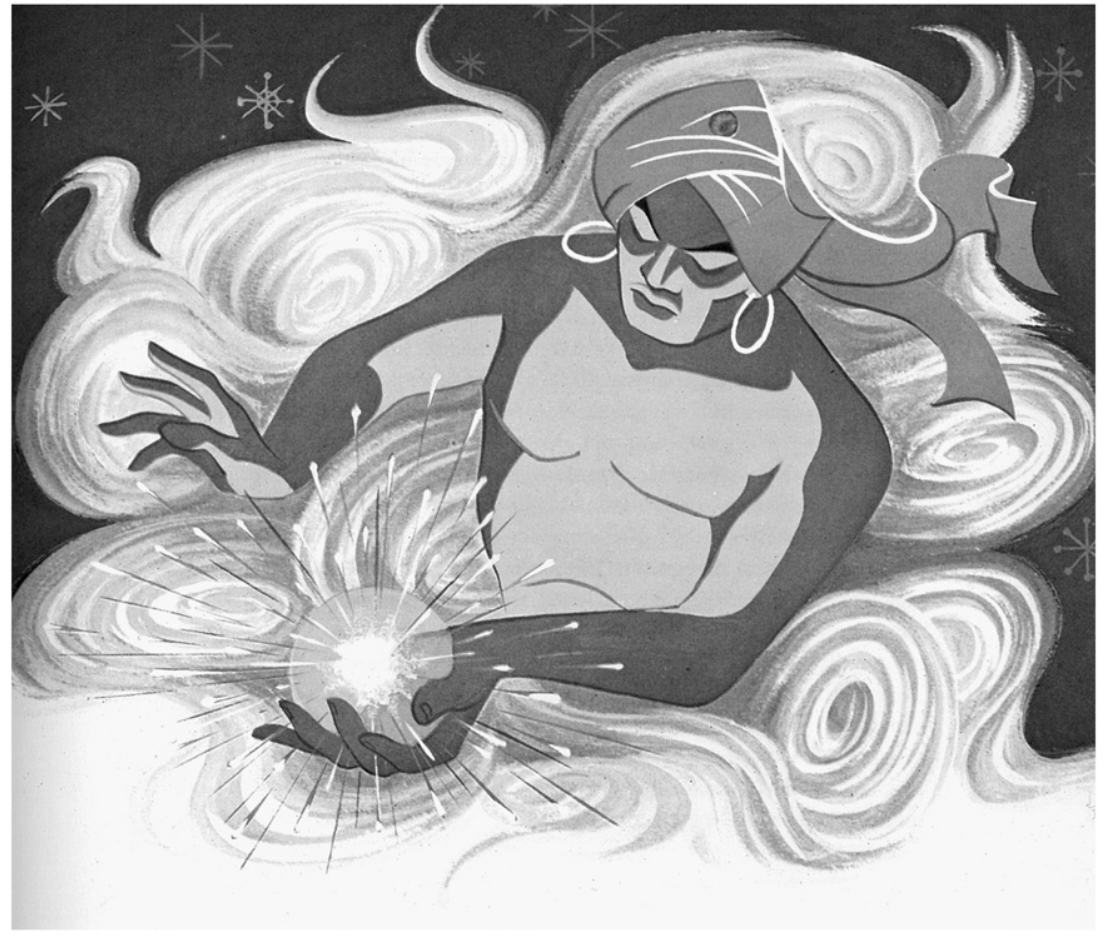

Fig. 9. Illustration from the Dutch version of Disney's educational children's book 'Our Friend the Atom' [47]. 

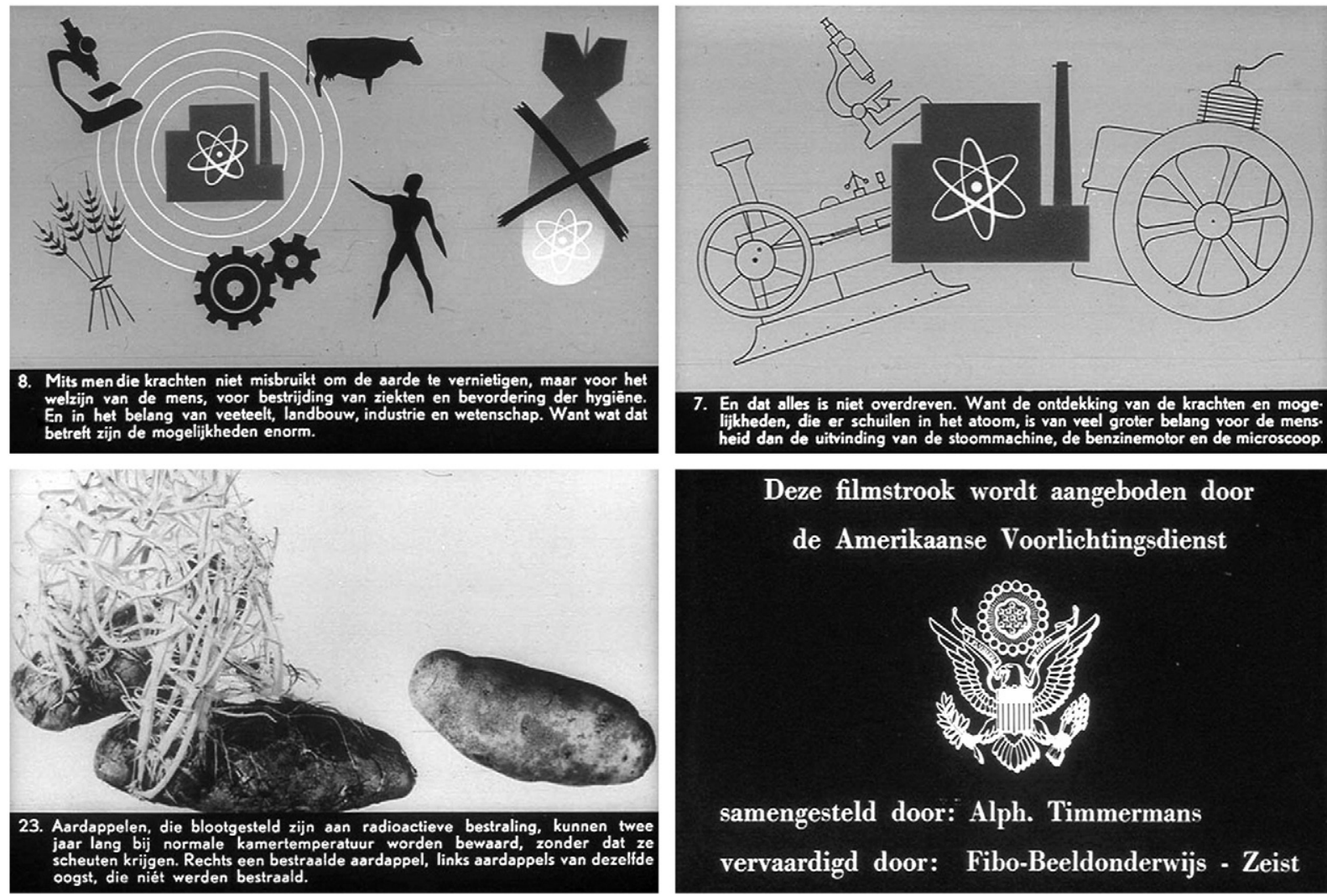

7. En dat alles is niet overdreven. Want de ontdekking van de krachten en moge. lifkheden, die er schuilen in het atoom, is van veel groter belang voor de mens. heid dan de uitvinding van de stoommachine, de benzinemotor en de microscoop

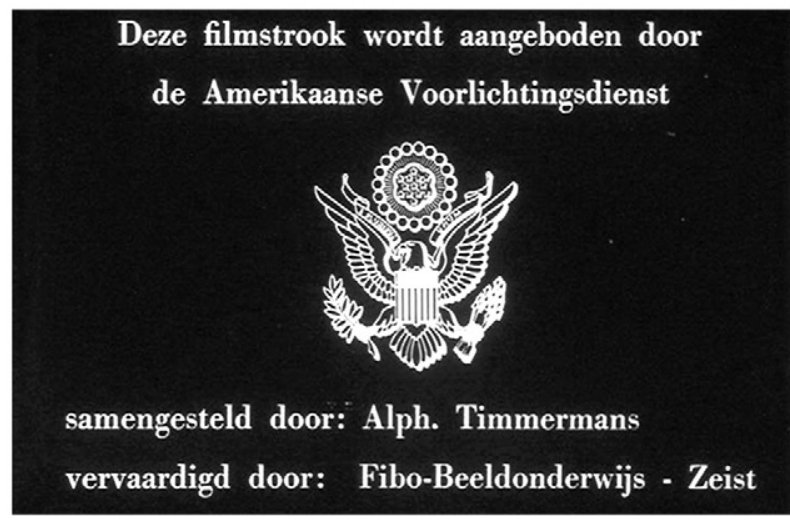

Fig. 10. Excerpts from educational slideshows in the mid-1950s. Top row from "Man and the Atom" [49], bottom row from "Blessings of the Atom" [48].

Netherlands in the mid-1950s as educational material. The top left corner slide emphasizes the peaceful uses of the atom, in contrast to atomic bombs. The top right corner slide embodies the technological progress motif, suggesting further that nuclear energy is a more important breakthrough than the steam engine, the internal combustion engine, or the microscope. The bottom left slide shows the benefits of radiating potatoes for conservation. This linking to people's daily lives enhanced the 'experiential commensurability' further discussed below.

\subsubsection{Experiential commensurability}

The vision of an 'Atomic Age' emerged when newspaper articles and books translated the abstract promise of nuclear energy to people's daily lives. Between 1954 and 1957, newspaper De Tijd ran a recurring section entitled 'Living With Atoms' in which the

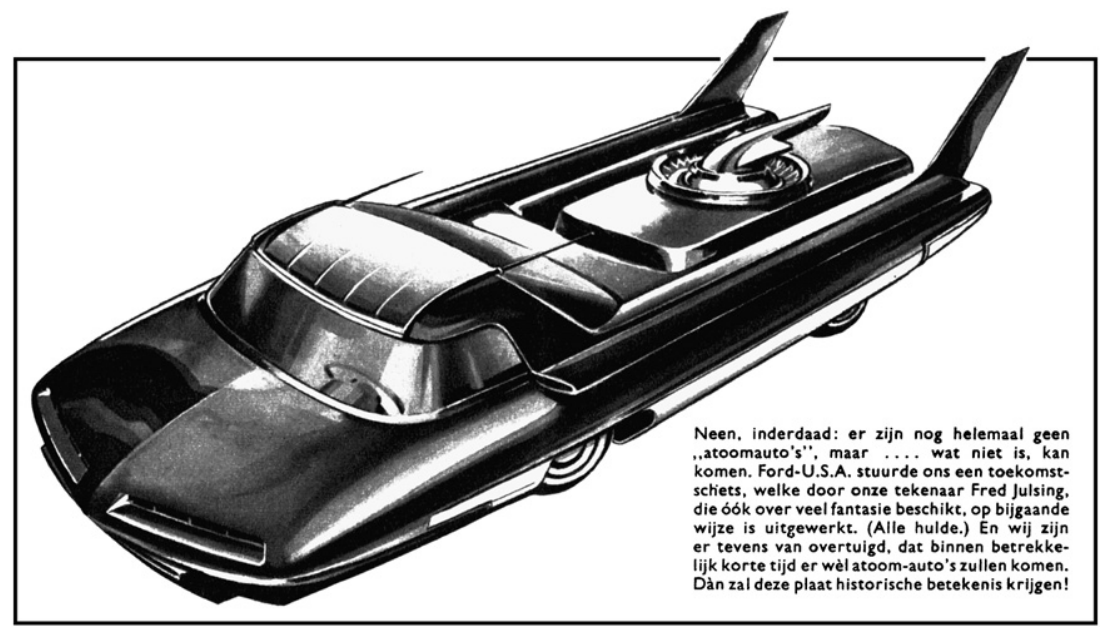

Fig. 11. The "Ford Nucleon", a nuclear-powered concept car [51]. 
benign effects of the atom on people's lives were discussed. This culminated in a popular scientific book [50], which told of the potential of radioactive isotopes in curing diseases, preserving foodstuffs, killing insects, finding leaks in pipes, making homogenous paints, and measuring the cleanness of laundry. Other visions, which related to people's daily life, promised that nuclear reactors would soon power civilian passenger ships, trains, and cars. Fig. 11 shows a Ford concept car, unveiled at the Detroit Motor Show of 1958 and reported in Dutch motorist club ANWB's magazine [51]. The caption reads: "We too are convinced that within a relatively short period of time, atom-cars will be available". Such framings, which emphasized the benefits for people's daily lives, aimed to make nuclear energy less strange and distant.

\subsubsection{Centrality}

The legitimacy of nuclear energy was also enhanced by linking it to industry; a central theme during the post-war reconstruction decades. Nuclear energy would deliver the cheap energy crucial for industrial and economic growth. In a 1954 speech to the National Association of Science Writers, US Atomic Energy Commission chairman Lewis Strauss famously promised that "our children will enjoy in their homes electrical energy too cheap to meter". The promise that nuclear energy would bring abundant and cheap energy enhanced the 'centrality' of the pro-nuclear discourse. By the mid-1950s the government articulated the ambition of creating a Dutch nuclear industry [52], and therefore began discussions with electricity producers and industry representatives about the construction of a full-scale commercial reactor. The utilities were hesitant, however, about its commercial feasibility.

The 1956 Suez crisis stimulated the awareness of the vulnerability associated with dependence on Middle Eastern oil and reinforced the desire for a new energy source. This created an opportunity to frame nuclear energy as an answer to a central social problem. A popular book, for instance, argued that:

"For Western Europe, the Suez crisis has been an omen (...). It is clear that it could be of the utmost importance for the independence of Western European energy supply if a larger share of the required energy would come from indigenous sources. From nuclear power plants, in other words." [50].

These framing efforts increased the centrality and public attention for nuclear power in newspapers in 1956 and 1957 (see Fig. 8). This increase was also related to the government's 1957 Memorandum on Nuclear Energy, which contained the ambitious goal of 50\% nuclear electricity production by 1975 . The Memorandum also enhanced pressure on the utilities by expressing the desire to connect a nuclear power plant to the electricity grid by 1962. Estimated costs were 9 billion Dutch guilders [53].

\subsubsection{Empirical fit}

To enhance the empirical fit with real-world events, pro-nuclear discourses pointed to foreign successes with nuclear submarines and commercial electricity generation. To further enhance the empirical evidence base, nuclear proponents organized exhibitions and trade shows that allowed the public to 'see for themselves'. The 1957 exhibition "Het Atoom", which was held at Schiphol airport drew 750,000 visitors [54] and highlighted peaceful applications of atomic energy in healthcare, agriculture, transportation, industry, scientific research and energy production. It also showcased an American $100 \mathrm{~kW}$ pool reactor, allowing visitors to see the first nuclear reactor on Dutch soil [54].

\subsubsection{Actor credibility}

In the period 1945-1955, the primary articulators of the pro-nuclear discourse were scientists. The establishment of FOM in 1946 had occurred on the advice of physicists who saw themselves as the primary representatives of nuclear power [52]. Scientists enjoyed high trust and actor credibility, as indicated by the following quote from the Zierikzeesche Nieuwsbode:

"Day and night, these scientists rack their brains for ways to rid themselves of the specter of the atomic bomb. When they point out its lethal dangers, it is only to instill a "healthy fear" into the people. They seek to guard the world of a dull apathy with the regard to the atomic bomb by stressing that there will always be desperados who would reach for this diabolic weapon in an ill-fated moment" [55].

During the 1950s, the discourse coalition behind nuclear energy broadened from FOM scientists to include actors within government, industry and utilities, who strengthened the interest in commercial benefits and the possibility of a Dutch nuclear industry. These actors had high credibility, because the 1950s and 1960s were characterized by technocracy, trust in experts and respect for authorities. Their credibility was reinforced by alignments with the repertoires of modernization and technical progress (discussed above), which gave authorities a societal mandate to restructure society.

\subsubsection{The result: high cultural legitimacy}

The cultural activities on several dimensions produced a plausible and salient pro-nuclear discourse that gave nuclear power high cultural legitimacy in the 1950s and 1960s. The only criticisms were about costs; some felt that 9 billion guilders was a high price to enter the Atomic Age [56].

In the context of this pro-nuclear discourse, the large-scale accident with the British Windscale nuclear reactor (1957), which led to substantial radioactive contamination, was not interpreted as a cause for alarm, but as an "irregularity". On 18 October 1957, 
the Zierikzeesche Nieuwsbode, for instance, mentioned "an irregularity at the Windscale nuclear plant", but reassured its readers that "thorough responses" had been taken, such as the "flushing the milk supplies from several nearby farmers".

As cultural legitimacy became established, attention shifted towards practical implementation and offstage negotiations between government, electric utilities and industry representatives. The utilities remained hesitant about the economic feasibility of nuclear energy, also because fuel oil and newly (1959) discovered natural gas formed feasible alternatives for electricity generation [52]. Because the government exerted political pressures, the utilities agreed in 1961 to build a nuclear plant that was big enough to learn from, but small enough not to result in large economical losses. Once the Law on Nuclear Energy (1963) provided a regulatory framework, construction of the 55 MW Dodewaard plant began in 1964 and started operation in 1969.

To stimulate the build-up of a Dutch nuclear industry, the government kept pushing for a second, larger plant. Electric utilities agreed to build this plant when the construction of an electricity-intensive aluminium factory in Borssele provided a guaranteed market for the generated electricity [interview with Storm van Leeuwen]. From the seven tenders for the $400 \mathrm{MW}$ plant, the utilities accepted a German proposal by Siemens in 1969 [52]. The Dutch government was not amused because this decision frustrated the build-up of a domestic nuclear industry. It had no legal means, however, to contest this decision. The Borssele plant began operation in 1973.

\subsection{The anti-nuclear movement and contestation of cultural legitimacy (1970-1986)}

In the 1970s, the cultural legitimacy of nuclear energy was challenged by an anti-nuclear movement (ANM), which emerged through the coalescence of different organizations. By 1970, Borssele inhabitants became worried about possible environmental pollution from the aluminium factory and nuclear power plant. Organizing themselves into the committee Borssele Ad Hoc, they filed many objections with the Ministry of Economic Affairs to influence the construction permit procedures [57]. Meanwhile, the 'Union of Engaged Scientists' (VWO), which had emerged in 1946 over concerns about nuclear armament, began to raise questions about nuclear reactor safety. Some VWO members joined the citizen protests to create the 'Working Group Nuclear Energy'. In 1972, the government issued a Memorandum on Nuclear Energy Policy, which proposed the construction of 35 nuclear power plants. In response, the Working Group wrote an alternative 'Nuclear Energy Memorandum' which did not fully reject nuclear power, but stressed the risks and uncertainties associated with radiation effects, waste problems and environmental pollution [58]. In 1972, the government also decided to participate in an experimental Dutch-German fast-breeder type nuclear reactor in Kalkar. In 1973, the government announced a 3\% tax levy on electricity bills to cover the extra costs. This 'Kalkar Tax' led to societal outrage and large-scale protests that galvanized the emergence of an anti-nuclear movement [interview with Bannink]. In September 1974, 10,000 activists protested in the German town of Kalkar, and in October 1974 protesters presented a petition of 155,000 signatures to government officials [59]. Dozens of local action groups coalesced into the 'National Power Groups Stop Kalkar' (LSSK). Stimulated by the attention from press, politicians and public opinion, this led to the creation of a full-fledged Dutch anti-nuclear movement (ANM).

In subsequent years, proponents and opponents to nuclear energy engaged in framing struggles over various specific issues. Proponents and opponents adjusted their frames as they responded to each other, to external events and to broader developments. They introduced new themes, coined new metaphors and developed new images. The analysis below traces how various actors attempted to increase the salience of their discourses by manoeuvring on various dimensions.

\subsubsection{Actor credibility (1970-1976)}

Because early anti-nuclear protests had a not-in-my-back-yard character, nuclear proponents could disqualify them as emotional or irrational non-experts [interview with Storm van Leeuwen]. This strategy became less feasible when protesters forged coalitions with concerned scientists, who had the technical expertise to question the pro-nuclear frame on scientific method, burden of proof, quality of data, and theoretical assumptions. The anti-nuclear movement thus gained credibility through the alliance with scientists. In 1976, a national newspaper advert by the 'Reflection Group Energy Policy' [60] offered calculations that showed that nuclear energy was unnecessary because regular power plants could meet projected electricity demand, unlikely to stimulate domestic industry, and too expensive because of increasing uranium prices. Because it was signed by 1200 scholars, the message had credibility. The alignment with science also changed the framing struggle between opponents and proponents from 'rational versus emotional arguments' to 'conflicting rational arguments'.

\subsubsection{Macro-cultural resonance (1970s)}

While the macro-repertoires of modernization and techno-scientific progress persisted, they were complemented in the 1970s by 'counter-culture' repertoires that contained themes such as 1) concern for environmental problems, 2) 'technology out of control', a notion that linked concerns about negative social side-effects to views of unstoppable technology, 3 ) technocracy, i.e. experts and authorities making decisions without democratic control, and 4) emancipation and demands for participation in decision-making processes. As respect for and obedience to authorities weakened, attitudes towards 'the establishment' became more critical.

The anti-nuclear discourse linked up with these new macro-repertoires. First, anti-nuclear protesters highlighted the environmental problems associated with radioactive waste. Second, they emphasized the risks and uncertainties with regard to radiation, waste, and accidents, and framed plans for nuclear power plants as 'technology out of control' [61], (Fig. 12). Radiation risks were especially highlighted because they were mysterious, invisible and threatening to the most vulnerable members of society (babies, children, pregnant women). Playing on notions of negative side-effects, posters [62] and other cultural 


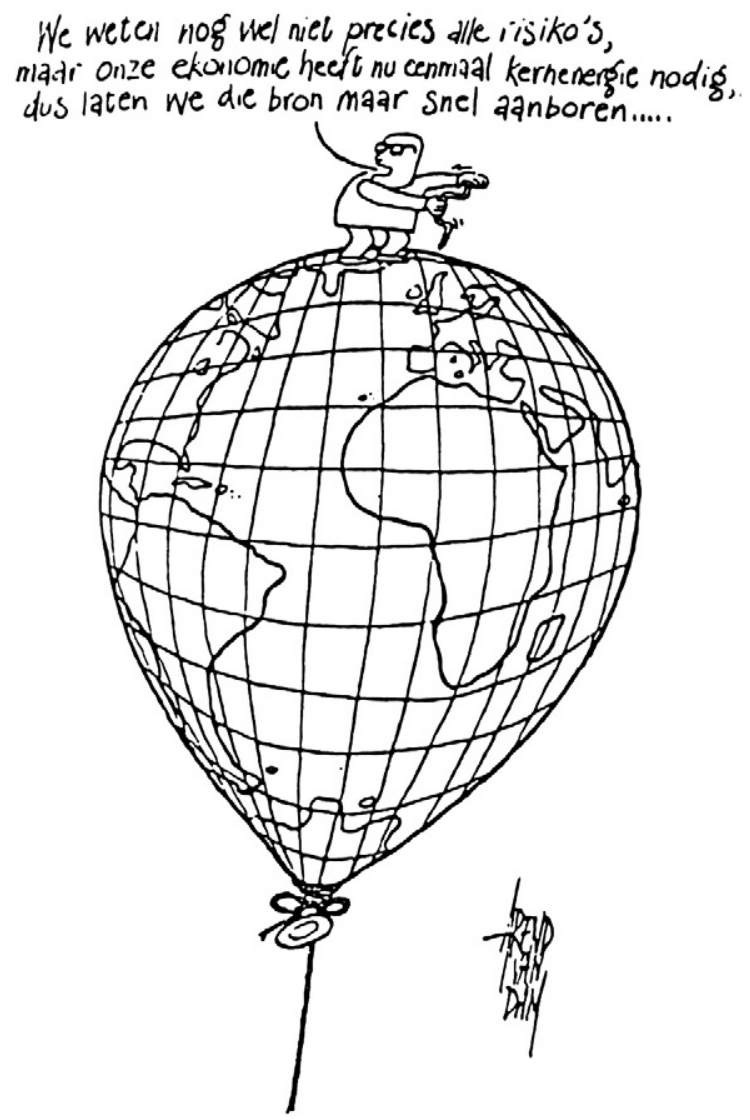

Fig. 12. Cartoon showing a scientist about to drill into a 'balloon earth', saying: "We're not exactly sure what the risks are yet, but our economy needs nuclear energy, so let's tap into the source quickly..." [61].

performances [59] suggested that radiation might induce genetic mutation leading to disfigured children (Figs. 13, 14). Third, antinuclear protesters played on the themes of technocracy and suspicion of 'establishment' experts, criticizing them for hiding risks and uncertainties [63], (Fig. 15). The implication was that experts and authorities could not be trusted to tell the truth, because they were influenced by political and industrial interests.

The counter-culture repertoires were not shared by everyone. Many policy makers, scientists, business managers, and citizens continued to subscribe to the macro-repertoires of inevitable technological progress. So, in the 1970s, both pro- and anti-nuclear frames resonated with different cultural deep structures.

\subsubsection{Centrality (1973-1976)}

The 1973 oil crisis led to heated public discussions about energy supply, which provided nuclear proponents with an opportunity to frame nuclear energy as a solution. The linking of nuclear power to pressing social problems increased its centrality. The government subsequently published a Memorandum on Energy [64] which tempered previous expectations, but announced the construction of three new plants by 1985. The Memorandum also increased the political control over nuclear energy by transferring decision power on nuclear issues to the government.

In response, the 'Reflection Group Energy Policy' published the 'Reflective Memorandum on Nuclear Energy' [65] which pleaded for a moratorium because of uncertainties and possible risks. In 1976, the same group published a full-page newspaper advertisement (31 January), asking members of Parliament for "the benefit of the doubt". They tried to reduce the centrality of nuclear power, arguing that "the [projected increase in energy] demand can be met by existing construction plans for regular power plants" and labeled "the suggestion that saying no to nuclear power means saying no to a good energy supply system" as "a dangerous myth".

\subsubsection{Empirical fit (1970-1978)}

Pro-nuclear discourses had a high empirical fit, because proponents could point to successful operation of nuclear plants domestically and abroad. These real-world events increased the legitimacy of their discourse. Nuclear opponents, on the other hand, were not able to mobilize real-world events to prove their views about risks and dangers. Their empirical fit was therefore low, which enabled nuclear proponents to criticize anti-nuclear sentiments. 


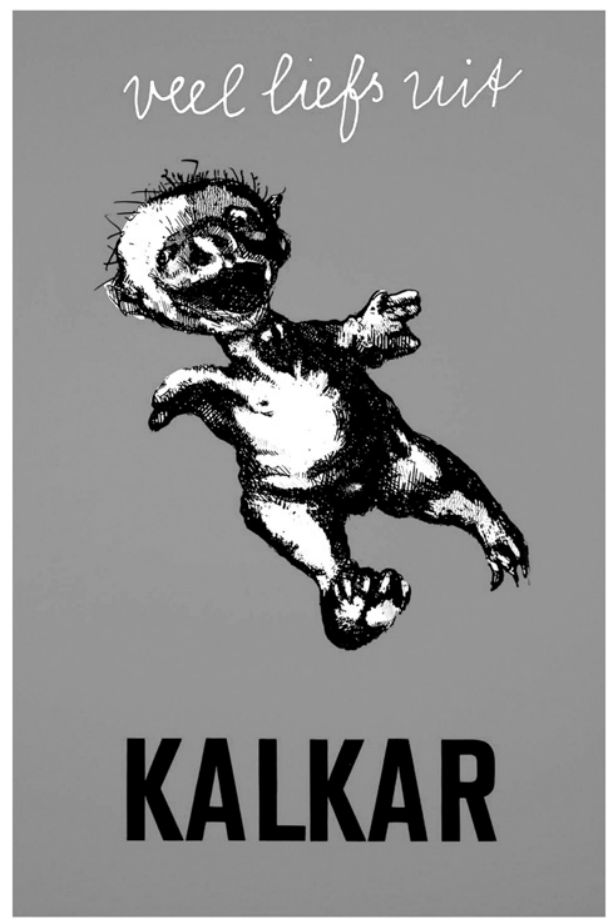

Fig. 13. Poster depicting disfigured baby, reading “Love from Kalkar”, designed for anti-nuclear group SSK in 1974 [62].

\subsubsection{Protests and experiential commensurability (1974-1981)}

Despite the 1950s' promises of nuclear automobiles, nuclear cooking etc., the first real influence nuclear energy had on people's daily life was the negative experience of the 'Kalkar tax'. This 'tactical error' of nuclear proponents led to the first protest marches [interview with Jansen], and tarnished the positive framing of nuclear energy. People increasingly experienced nuclear energy as a contested issue which was performed on the evening news through protest marches and debates and discussed in talk shows. The

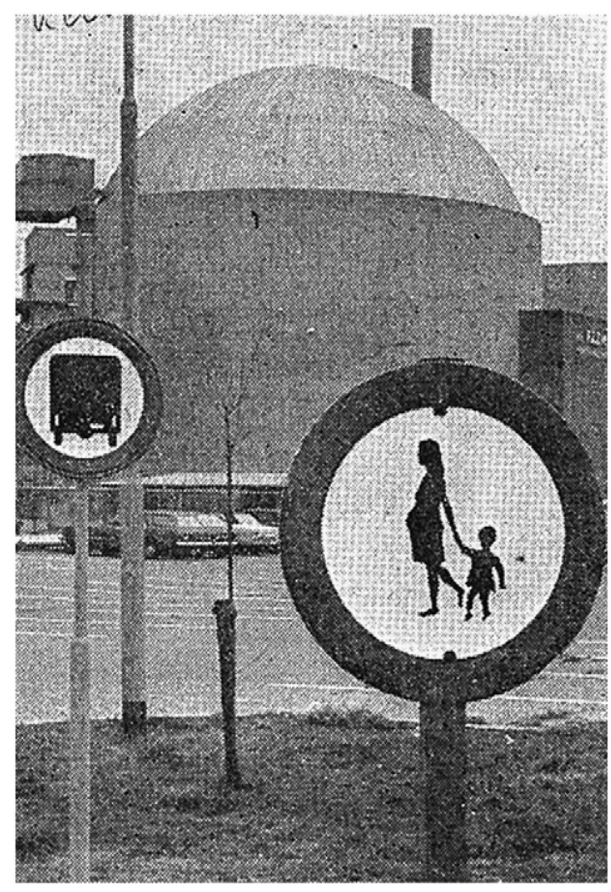

Fig. 14. Photograph of home-made traffic sign at the Borssele plant, implying by association "no entry for pregnant women and children". It was placed by anti-nuclear activists on 3 March 1974 to call attention to the fact that extant radiation norms applied to healthy men, who are less susceptible to the effects of radiation [59]. 


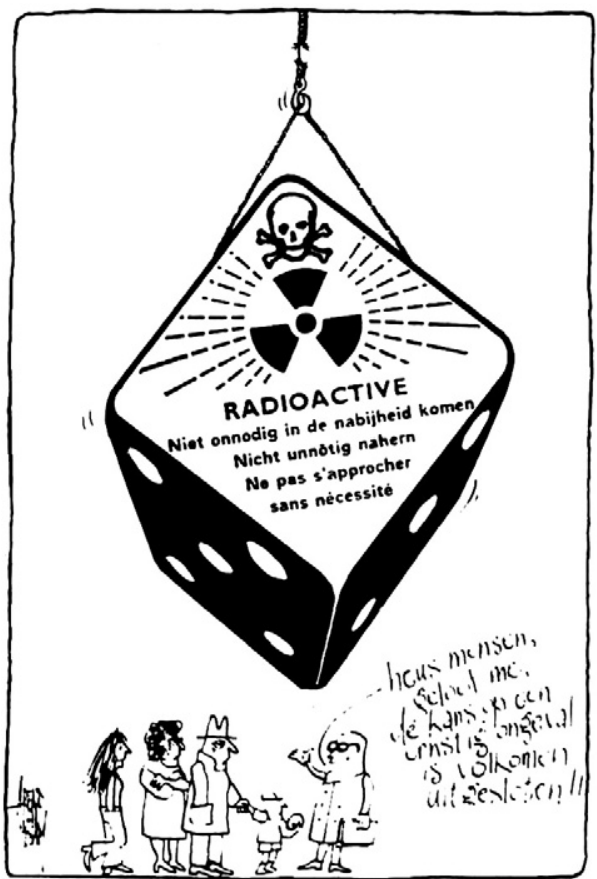

\section{"Geen onzekerheden in de voorlichting".}

Fig. 15. The cartoon shows a radioactive die (a symbol of gambling) with the words "radioactive - do not approach unnecessarily", hanging like a sword of Damocles above the public. A scientist exclaims: "Really people, believe me, the odds of a serious accident are zero". The caption reads "No uncertainties in education" [63].

largest protest march with about 50,000 people occurred in 1978, in response to expansion plans of Urenco's uranium-enrichment facility [59]. The protests had little effect, because political parties supported the expansion plans in Parliament. Some members within the anti-nuclear movement (ANM) felt increasingly frustrated, since petitions and protest gatherings seemed ineffective. At the same time, political activists with a broader opposition agenda joined the ANM. They were less interested in environmental or risk issues, but saw the nuclear issue as an arena for their radical agenda [interview with Bannink]. Both developments contributed to a schism in the ANM and the creation of a radical wing that favored direct action and, in some cases, violence [44,57]. In 1980 this resulted in the Dodewaard-Gaat-Dicht (DGD) blockade by 300 autonomous 'base groups' of 10-15 members each. DGD adopted more radical goals and demanded the closure of all existing plants. The second Dodewaard-Gaat-Dicht blockade in 1981 escalated and resulted in violent confrontations with the military police which received widespread media attention (Fig. 16).

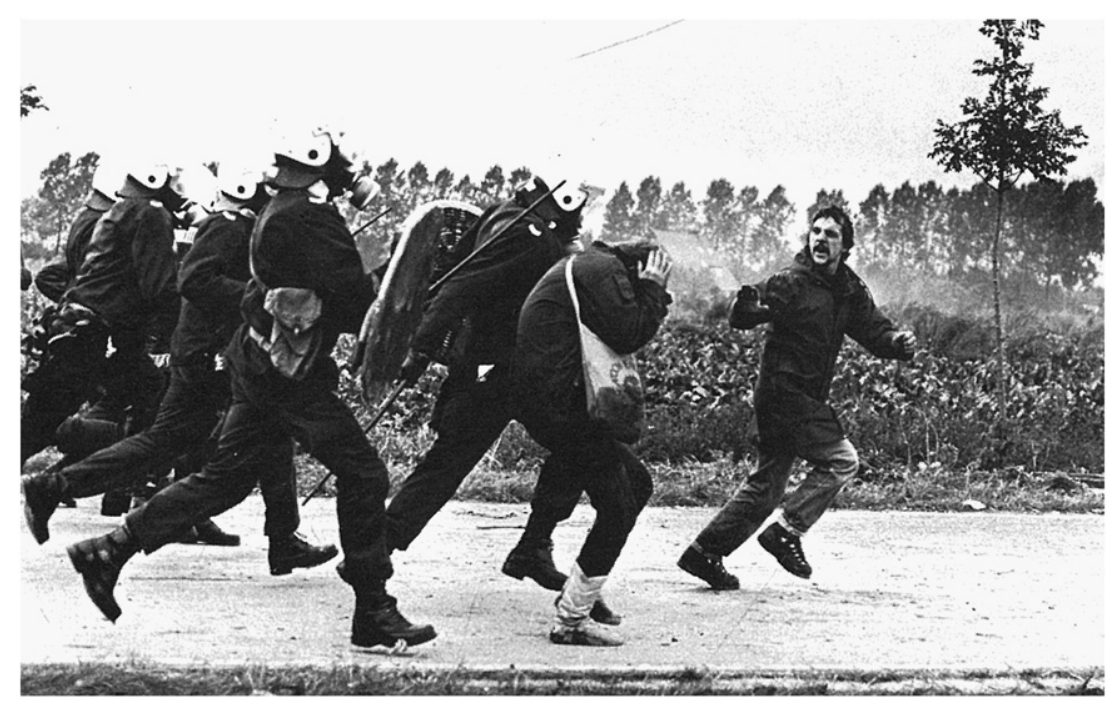

Fig. 16. This photograph of military police beating a protester at Dodewaard-Gaat-Dicht blockade of 1981 was used in ANM publication to illustrate claims of police brutality [66]. 


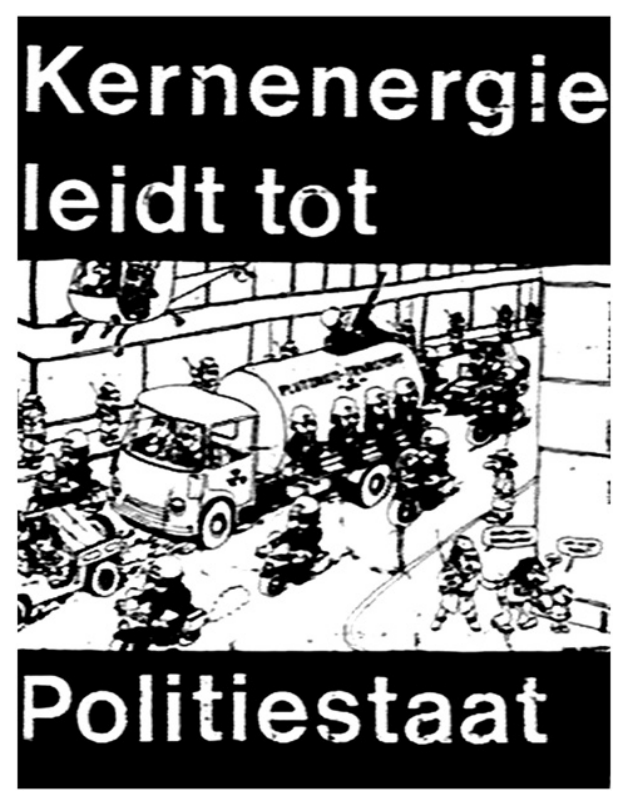

Fig. 17. Poster performing the authoritarian discourse of nuclear power, reading "Nuclear energy leads to a police state" [67].

These experiences politicized the radical wing's discourse, which framed the struggle not just as against nuclear energy, but also as against a repressive state, which used police force to implement nuclear power (Figs. 17, 18).

\subsubsection{Effects of radicalization: actor credibility, experiential commensurability and centrality}

The radicalization of the ANM had two counter-acting effects. On the one hand, it undermined their credibility and experiential commensurability. The general public could not identify with the views of the radical ANM wing or their violent actions, which reduced their perceived legitimacy. The radical discourse and performances thus alienated the ANM from the general public and gave nuclear proponents the chance to frame the anti-nuclear protesters as anarchist troublemakers. The radical protest actions therefore lowered the credibility and experiential commensurability of the anti-nuclear discourse. On the other hand, radical

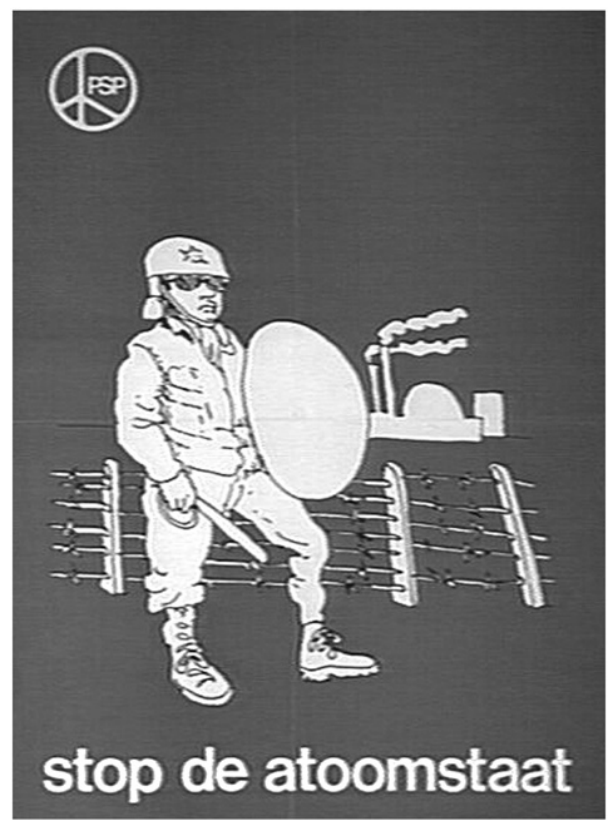

Fig. 18. Poster by pacifist socialist party PSP, reading "Stop the atomic state" [68]. 
actions increased the centrality of nuclear energy in public opinion and political debate. The climate of polarization people produced a stalemate between the two opposing camps [57,69].

To defuse the debate and overcome polarization, the government agreed to organize a Broad Societal Discussion [interview with Jansen]. The BSD was seen both a tool to overcome the stalemate and as a democratic experiment for dealing with controversial issues. Preparations began in 1979, and the actual registration of opinions and (hundreds of) moderated, decentralized discussion evenings took place in 1982 and 1983.

\subsubsection{Harrisburg (1979) and empirical fit}

During preparations for the BSD, a major accident occurred in the Three Mile Island nuclear power plant in Harrisburg, USA (1979). Unlike the 1957 Windscale accident, an anti-nuclear frame was now in place which allowed the accident to be interpreted as empirical evidence for the risks associated with nuclear power. Harrisburg thus enhanced the empirical fit of the anti-nuclear discourse and led to large-scale protests, with thousands of people rallying outside the Borssele nuclear power plant. The accident enhanced the legitimacy of the anti-nuclear frame and turned the tables in the sense that nuclear proponents now had to prove that nuclear energy was safe. One pro-nuclear rhetorical strategy was to highlight design differences, for instance in safety systems. The chairman of the Dutch committee of reactor safety claimed that "both our country's nuclear power plants differ in construction from the Harrisburg plant and hence, the chances of a similar accident occurring here are significantly smaller." [70]. Another strategy was to blame human error. Robert Benero, member of the American Nuclear regulatory Commission, claimed that the accident "probably occurred because the automatic cooling systems could not tolerate human intervention" [71]. A third strategy was to argue that it was only a partial meltdown, suggesting that reactor failures are ultimately controllable [interview with Storm van Leeuwen].

\subsubsection{The BSD and experiential commensurability (1979-1982)}

Although the BSD claimed to be about energy in general, it was primarily about nuclear power. The BSD intended to bring nuclear energy decision-making closer to the people, by allowing them to express their views. ANM-members were also invited to this government-controlled arena. Nuclear proponents were not enthusiastic about the BSD, which they felt was unnecessary and futile. They did not see the point in "treating emotionally determined statements equal to rationally substantiated ones" [72]. They nevertheless participated because they hoped for a 'rationalization of arguments' and recouping public support [73]. The General Energy Council (AER), a conservative advisory body to the government, hoped that the BSD would finally overcome the disagreements and provide solid grounds for final decision-making: "After the (...) discussion, there should be no more grounds for the view that insufficient opportunity for the formation of opinions has existed". It also hoped that the BSD would make a "clear-cut distinction (...) between hard facts (...) and uncertainties and value judgments" [74].

While moderate ANM-members decided to participate in the BSD, radical members did not, because they felt that it would either be a futile exercise or an exercise for which the outcome was predetermined [75]. They also saw the process as a means by which the government tried to "neutralize societal resistance to nuclear power through objectifying and rationalizing arguments and emotions" [76].

\subsubsection{The BSD and centrality (1982-1983)}

When actual discussions started in 1982 and 1983, the centrality of nuclear energy was declining (see also Fig. 8) as other issues, such as the economic recession and rapidly increasing unemployment, became more central in public opinion and policy debates. Turnouts at the discussion meetings were lower than expected. Although the Steering Group had hoped for 35,00050,000 participants, only 19,000 people attended the information meetings, the discussion meetings or both [72]. Furthermore, the BSD functioned more as performance stage than as debating forum: actors expressed their existing views, while virtually no one changed their mind [interview with Jansen].

In 1984, the Steering Group summarized the findings in a report, which concluded that a limited group of participants (17$26 \%$ ) favored the continued operation of the current plants and the construction of new ones. A larger group (33-58\%) rejected nuclear power and wanted short-term closure of existing plants. About $16-40 \%$ favored the continued use of existing plants, but no further expansion. The end report also stated "never before has Parliament been able to take its decisions armed with the knowledge of opinions by so many, regarding so many aspects of one complex problem" [72].

\subsubsection{Ignoring the BSD and macro-cultural resonance (1984-1985)}

The BSD's conclusions, which spoke out against new construction, were overruled by political powers. First, the AER rejected the conclusions, advising the government that "deployment of uranium as an energy carrier should be considered" as part of energy diversification policy. Following this advice, the government officially rejected the BSD conclusions in 1985 in a letter to Parliament, where it was backed by a political majority. The government proposed the construction of two new nuclear power plants, citing international engagements, energy diversification, and cheap electricity as main reasons. A parliamentary majority agreed and in January 1986 the government designated three locations as potential construction sites for the new plants [57].

These decisions neither revitalized the antinuclear movement nor led to major protests. But they did enhance the macrocultural resonance of the technocracy theme in the anti-nuclear frame, i.e. the view that policy makers and nuclear proponents 
push through nuclear energy against the 'will of the people'. A contribution to the Leeuwarder Courant [77] expressed this view, commenting that the decision marked:

“(...) a sad day for the credibility of politics. (...) A slap in the face of tens of thousands of citizens who have seriously participated in the discussion and hundreds of thousands who have seriously believed in its social use and political weight. (...) Minister Van Aardenne acknowledged that the discussion served a different purpose than its participants thought. Its goal was to calm down heated temperaments. (...) A thirty-million-guilders-costing charade was enacted, a statesponsored exorcism to incapacitate the demons of ignorant folk beliefs and to expel them using their own weapon: participation. (...) It is not exaggerated to speak of the arrogance or hubris of power. It is now openly admitted that citizens have been used for other purposes than they thought."

\subsubsection{Chernobyl (1986): empirical fit, centrality and credibility}

The Chernobyl meltdown (April 1986) revitalized the anti-nuclear discourse, because nuclear opponents could now claim they had been right all along. Because of Chernobyl the anti-nuclear discourse scored well on centrality, empirical fit and credibility, Chernobyl also increased the score on experiential commensurability, because radioactive fallout led to bans on daily consumer products such as milk, lettuce and spinach. Chernobyl also injected emotion and macro-cultural resonance into the anti-nuclear frame, especially anger over technocracy and the government's previous decision to ignore the BSD outcome. A submitted letter to the Leeuwarder Courant [78] read:

"[T]he so-called Broad Societal Discussion [showed that] two thirds of the Dutch population does not want (...) new nuclear power plants. The current CDA/VVD coalition did not let this influence them. The atomic lobby - headed by Gijs Van Aardenne [Minister of Economic Affairs] - has simply swept the BSD report under the table. If those new plants are not constructed, it will be thanks to the Chernobyl disaster, but let's not claim that the Western peoples were meaningfully involved in the process."

Because the Dutch anti-nuclear discourse scored high on many plausibility and salience dimensions, Chernobyl came to be interpreted as a decisive reason to halt nuclear expansion [interview with Storm van Leeuwen]. Nuclear energy dominated the campaigns for the Parliamentary elections, scheduled for 21 May 1986. Christian-democrats and liberals, both in favor of nuclear energy, were strongly attacked because of their nuclear expansion plans. Under strong public pressure, they had to abandon their pro-nuclear views (Fig. 19).

Although the Christian-democrat and liberal parties were re-elected, nuclear expansion plans disappeared and were not revitalized until the early 2000s, when climate change formed a new social problem to which nuclear energy became linked.

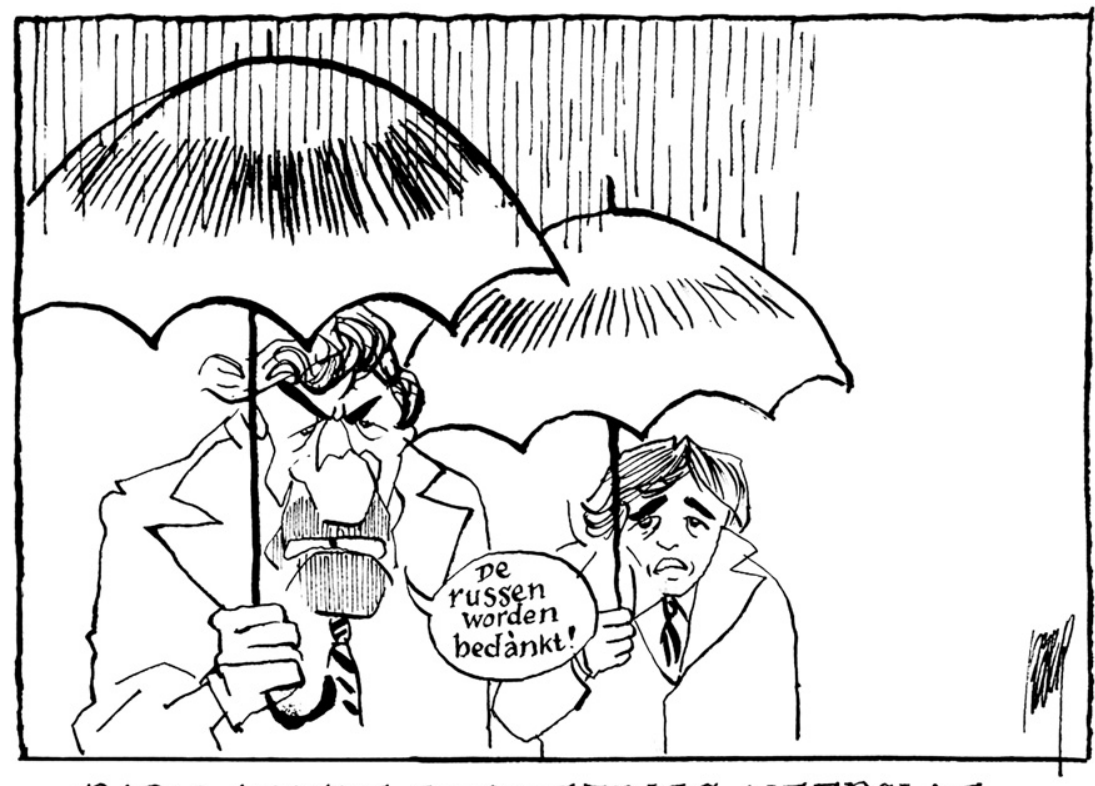

RADIO-ACTIEVE VERKIEZINGS-NEERSLAG

Fig. 19. Political cartoon illustrating the influence of the Chernobyl disaster on the general elections. CDA prime minister Ruud Lubbers, a vocal supporter of nuclear energy says "Thanks, Russians". The caption reads: "radioactive election-downpour" [79]. 


\section{Analysis}

The overall pattern is that cultural performances in the 1950s articulated a positive nuclear discourse that created high cultural legitimacy. In the 1960s, concrete decisions were made about financial investments and the construction of nuclear plants. While these decisions were influenced and legitimated by the previously constructed positive discourse, economic considerations and political struggles also played a role (e.g. between nuclear industry, electric utilities and government over reactor designs and speed of implementation). So, while cultural legitimacy was important, we do not advocate cultural determinism.

The cultural legitimacy weakened in the 1970s and 1980s, when opponents and proponents engaged in discursive struggles, which was played out through several stages: initial questioning of nuclear energy (1970-1973), increasing organization and opposition (1974-1979), escalation into a stalemate (1979-1981), Broad Societal Discussion (1980-1984) to overcome the stalemate, political overruling of BSD outcomes (1984-1986), and strong revival of anti-nuclear discourse following Chernobyl (1986).

The content of the pro- and anti-nuclear discourses changed during the struggle, as actors adjusted the framing of specific issues in response to each other's performances and to broader events. These specific framing struggles influenced the plausibility and salience of pro- and anti-nuclear discourses. Table 1 plots how the 'scoring' of both discourses on different analytical dimensions changed over time. Until 1979 the anti-nuclear frame was increasing in strength, because the discourse resonated well with broader cultural repertoires, because alliances with scientists enhanced their credibility, and because publicized protest marches enhanced the centrality and visibility. With regard to empirical proof and linkages to people's daily life, however, the anti-nuclear frame scored less in that period. The escalation of radical wings after 1979 contained performances that weakened the ANM, especially with regard to credibility, empirical fit and experiential commensurability. Harrisburg (1979) enhanced the empirical fit, however, providing evidence of nuclear risks. The early 1980s provided new challenges, because economic problems lowered the centrality of nuclear energy. Although the BSD restored the credibility of moderate nuclear opponents, nuclear energy lost centrality. Chernobyl strengthened the anti-nuclear discourse again, because it reinforced centrality, empirical fit and experiential commensurability (Table 1 ).

The effects of cultural legitimacy were indirect rather than deterministic. Policy makers and industrialists can ignore cultural legitimacy, although this creates risks. As the anti-nuclear frame gathered strength, the government hesitated about its 1974 plan to construct three new nuclear power plants. In 1978, when the anti-nuclear discourse reached its zenith, the government postponed this plan because of low cultural legitimacy. Instead, they organized the Broad Societal Discussion to overcome the stalemate. At the same time, however, they did push through the expansion of Urenco's uranium-enrichment facility, despite large-scale protests. For this smaller issue, they were thus prepared to confront public opinion. Nuclear expansion plans were revitalized in 1985, when the government rejected the outcomes of the BSD. They decided to push ahead, because, the cultural legitimacy of the anti-nuclear discourse had weakened, especially on the dimension of centrality (Table 1). Although political power overruled cultural concerns, this action strengthened the empirical fit of the anti-nuclear's notion that technocrats and politicians were not interested in the 'will of the people', which was expressed in the BSD. In the aftermath of Chernobyl, this notion came back to haunt the government as nuclear opponents reminded the public of their 'misuse of power', forcing them into atonement and rejection of nuclear expansion plans.

Cultural discourses also influenced the interpretation of nuclear accidents. The Windscale accident (1957), which occurred when nuclear energy was framed positively, was interpreted as an irregularity. Because anti-nuclear discourses hardly existed in the 1950s, it was literally unthinkable to interpret the accident otherwise. Harrisburg (1979), however, which occurred when the anti-nuclear discourse was strong, was interpreted as evidence of the nuclear risk framing. Chernobyl (1986) ended nuclear expansion plans, because it was interpreted as definitive proof of nuclear risks. Furthermore, this interpretation was laden with

Table 1

Varying scores of nuclear discourses on cultural dimensions.

\begin{tabular}{|c|c|c|c|c|c|}
\hline & Actor credibility & Empirical fit & Centrality & Experiential commensurability & Macro-cultural resonance \\
\hline \multicolumn{6}{|c|}{ 1945-1953 (atomic bomb): } \\
\hline Pro-nuclear & ++ & + & 0 & - & - \\
\hline \multicolumn{6}{|c|}{ 1953-1970 (Nuclear Age): } \\
\hline Pro-nuclear & ++ & ++ & + & $+1-$ & + \\
\hline \multicolumn{6}{|c|}{ 1970-1979 (contestation): } \\
\hline Pro-nuclear & + & + & + & + & + \\
\hline Anti-nuclear & + & 0 & + & 0 & + \\
\hline \multicolumn{6}{|c|}{ 1979-1981 (escalation): } \\
\hline Pro-nuclear & + & $+1-$ & + & $+1-$ & 0 \\
\hline Anti-nuclear & - & $+1-$ & + & - & $+/-$ \\
\hline \multicolumn{6}{|c|}{ 1981-1986 (BSD): } \\
\hline Pro-nuclear & + & + & - & 0 & 0 \\
\hline Anti-nuclear & + & 0 & - & 0 & 0 \\
\hline \multicolumn{6}{|c|}{1986 (Chernobyl): } \\
\hline Pro-nuclear & -- & - & +++ & - & 0 \\
\hline Anti-nuclear & + & ++ & +++ & ++ & 0 \\
\hline
\end{tabular}


anger, because the authorities had ignored the BSD outcomes, which were retrospectively interpreted as wise and correct advice. The conclusion is that the meaning of accidents is not fixed, but instead arises from the discursive frame that is mobilized.

Koopmans and Duyvendak [24] found that Chernobyl triggered few protest marches in the Netherlands, compared to France, Germany, and Switzerland. They interpreted this as indication of the weakness of the Dutch anti-nuclear movement (ANM). While we agree with this interpretation, our analysis shows that the ANM did not exert influence through direct protest marches (which authorities often ignored), but, more indirectly, through the discourses they performed. So, although nuclear proponents outmanoeuvred the ANM on political dimensions, they eventually 'lost' on cultural dimensions, in particular through the revitalized discourse after Chernobyl.

\section{Conclusions and discussion}

This article has contributed to the innovation studies literature by addressing the role of cultural dynamics in innovation journeys. Building on insights from interpretive, discursive and performative approaches to culture, we developed a new perspective on framing struggles for cultural legitimacy. Because the (management) literature already acknowledges the effects of cultural legitimacy on innovation journeys, we specifically theorized the mechanisms that influence the creation of cultural legitimacy. Mobilizing insights from social movement theory we also operationalized these mechanisms with five dimensions that determine the plausibility and salience of cultural discourses.

The case study demonstrated the usefulness of our perspective for analyzing the development of cultural legitimacy during innovation journeys. It also showed that our multi-dimensional operationalization facilitates a detailed analysis of the plausibility and salience of cultural discourses over time. Our perspective thus goes beyond the notion that 'everything is culture' (which may be true but provides few analytical insights) and beyond analyses that only trace the evolution of discourses (which are open to criticisms of describing 'just talk'). Our performative analysis instead pays attention to the (changing) content of discourses, their performance on public stages, and their 'legitimacy score'.

The case study also showed that the creation of positive meanings in early phases of innovation journeys is an important precondition for subsequent diffusion, because they influence investments and external support. But cultural legitimacy should not be taken-for-granted and needs to be maintained in later phases of innovation journeys. This did not happen in the case study, where positive framings and legitimacy were undermined in the 1970s and 1980s, which resulted in halting the expansion of nuclear energy.

While our perspective has proved generally useful, we make three qualifications. First, while cultural deep structures are part of our perspective (as something actors draw upon), their dynamics remain exogenous. In our case study, for instance, the emergence of a counter-culture and new repertoires in the 1970s is not explained. Second, nuclear energy is a specific case with important roles for policy makers (through responsibility for energy policy) and public opinion. While other studies suggest that cultural dynamics are also important in commercial cases, e.g. [2,9], the usefulness of our perspective for these cases has not yet been explicitly demonstrated. Third, from social movement theory we mobilized insights about framing processes and resource mobilization, but downplayed ideas about political opportunity structures (such as the strength/weakness of the state vis-à-vis the market and civil society, the degree of state hierarchy, the role of the judiciary) [80]. Our perspective does not incorporate political opportunity structures, because it focuses on cultural performances. Our perspective thus focuses on a particular cross-section of innovation journeys, and does not claim to explain everything. In future research, however, more attention for political opportunity structures can be useful to further articulate the conditions under which cultural legitimacy has more or less influence on political decisions. Future research could also apply our perspective to the revival of nuclear energy in recent years, analyzing how changing repertoires (around 'climate change') and new framings of nuclear energy (as 'renewable energy') have created new legitimacy. We expect that the underlying framing struggles vary between countries and influence the direction of innovation journeys.

\section{Acknowledgements}

We gratefully acknowledge financial support from the European Research Council (Geels) and the KSI program (Verhees). We thank A. Rip, A.A. Albert de la Bruhèze and the two anonymous referees for their constructive comments on a previous version of this paper.

\section{References}

[1] R.P.J.M. Raven, G.P.J. Verbong, Dung, sludge and landfill: social embedding biogas technology in the Netherlands, 1970-2000, Technol. Cult. 45 (3) (2004) 519-539.

[2] F.W. Geels, T. Pieters, S. Snelders, Cultural enthusiasm, resistance and the societal embedding of new technologies: psychotropic drugs in the 20th century, Technol. Anal. Strateg. 19 (2) (2007) 145-165.

[3] J.J. Deuten, A. Rip, J. Jelsma, Societal embedding and product creation management, Technol. Anal. Strateg. 9 (2) (1997) 131-148.

[4] C. Johnson, T.J. Dowd, C.L. Ridgeway, Legitimacy as a social process, Annu. Rev. Sociol. 32 (2006) 60

[5] W.R. Scott, Institutions and Organizations, Sage publications, Thousand Oaks, CA, 1995.

[6] M.C. Suchman, Managing legitimacy: strategic and institutional approaches, Acad. Manege. Rev. 20 (3) (1995) 574.

[7] A. van de Ven, D. Polley, R. Garud, S. Venkataraman, The Innovation Journey, Oxford University Press, New York, NY, 1999.

[8] S. Jacobsson, V. Lauber, The politics and policy of energy system transformation: explaining the German diffusion of renewable energy technology, Energ. Policy 34 (3) (2006) 272. 
[9] H. Lovell, Discourse and innovation journeys: the case of low energy housing in the UK, Technol. Anal. Strateg. 20 (5) (2008) 613-632.

[10] A. Bergek, S. Jacobsson, B.A. Sandén, 'Legitimation' and 'development of positive externalities': two key processes in the formation phase of technological innovation systems, Technol. Anal. Strateg. 20 (5) (2008) 581.

[11] H.E. Aldrich, M.C. Fiol, Fools rush in? The institutional context of industry creation, Acad. Manege. Rev. 19 (4) (1994) 645-670.

[12] M. Lounsbury, M.A. Glynn, Cultural entrepreneurship: stories, legitimacy, and the acquisition of resources, Strateg. Manage. J. 22 (6-7) (2001) 545-564.

[13] M. Lounsbury, M. Ventresca, P.M. Hirsch, Social movements, field frames and industry emergence: a cultural-political perspective on US recycling, Socio Econ. Rev. 1 (1) (2003) 71-104.

[14] T. Pollock, V. Rindova, V., Media legitimation effects in the market for initial public offerings, Acad. Manage. J. 46 (5) (2003) $631-642$.

[15] J.H. Freeman, G.R. Carroll, M.T. Hannan, The liability of newness: age dependence in organizational death rates, Am. Sociol. Rev. 48 (5) (1983) 692-710.

[16] M.A. Zimmerman, G.J. Zeitz, Beyond survival: achieving new venture growth by building legitimacy, Acad. Manege. Rev. 27 (3) (2002) 414 431, p. 414, 416.

[17] C. Oliver, The antecedents of deinstitutionalization, Organ. Stud. 13 (4) (1992) 563-588.

[18] G.F. Davis, K.A. Diekmann, C.H. Tinsley, The decline and fall of the conglomerate firm in the 1980s: the deinstitutionalization of an organizational form, Am. Sociol. Rev. 59 (4) (1994) 547-570.

[19] A. Swidler, Culture in action: symbols and strategies, Am. Sociol. Rev. 51 (2) (1986) 273-286.

[20] M. Hajer, J. Uitermark, Performing authority: discursive politics after the assassination of Theo van Gogh, Public Admin. 86 (1) (2008) 5-19.

[21] L. Spillman, Cultural Sociology, Blackwell Publishers, Malden, MA, 2002.

[22] R.D. Benford, D.A. Snow, Framing processes and social movements: an overview and assessment, Annu. Rev. Sociol. 26 (2000) 619.

[23] B. Flyvbjerg, Five misunderstandings about case-study research, Qual. Inq. 12 (2) (2006) 229.

[24] R. Koopmans, J.W. Duyvendak, The political construction of the nuclear energy issue and its impact on the mobilization of Anti-Nuclear Movements in Western Europe, Soc. Probl. 42 (2) (1995) 235-251.

[25] T. Parsons, The Social System, Free Press, Glencoe, IL, 1951.

[26] C. Lévi-Strauss, Structural Anthropology, Basic Books, New York, NY, 1963.

[27] C. Rojek, B. Turner, Decorative sociology: towards a critique of the cultural turn, Sociol. Rev. 48 (4) (2000) $629-648$.

[28] J.C. Alexander, Cultural pragmatics: social performance between ritual and strategy, Sociol. Theor. 22 (4) (2004) 527-573.

[29] M. Hajer, The Politics of Environmental Discourse: Ecological Modernization and the Policy Process, Clarendon Press, Oxford, 1995.

[30] A. Rip, S. Talma, Antagonistic Patterns and New Technologies, in: C. Disco, B.J.R. van der Meulen (Eds.), Getting New Technologies Together, Berlin/New York, Walter de Gruyter, 1998, p. 301.

[31] B. Pfaffenberger, Technological dramas, Sci. Technol. Hum. Val. 17 (3) (1992) 282-312.

[32] H. van Lente, Promising Technology: The Dynamics of Expectations in Technological Development, Eburon, Delft, 1993.

[33] N. Brown, M. Michael, The sociology of expectations: retrospecting prospects and prospecting retrospects, Technol. Anal. Strateg. 15 (1) (2003) 3-18.

[34] J. McCarthy, M. Zald, Resource mobilization and social movements, Am. J. Sociol. 82 (1977) 1212-1241.

[35] R. Eyerman, A. Jamison, Social Movements: A Cognitive Approach, The Pennsylvania State University Press, University Park, PA, 1991.

[36] R.K. Yin, Case Study Research: Design and Methods, 2nd ed.Sage Publications, Thousand Oaks, CA, 1994.

[37] P. Hedström, R. Swedberg, Social Mechanisms: An Analytical Approach to Social Theory, Cambridge University Press, Cambridge, 1998.

[38] M. Bunge, How does it work? The search for explanatory mechanisms, Philos. Soc. Sci. 34 (2) (2004) 182-210.

[39] W.A. Gamson, A. Modigliani, Media discourse and public opinion on nuclear power: a constructionist approach, Am. J. Sociol. 95 (1) (1989) 1-37.

[40] J. Newig, Public attention, political action: the example of environmental regulation, Ration. Soc. 16 (2) (2004) 149-190.

[41] A. Abbott, From causes to events: notes on narrative positivism, Sociol. Method. Res. 20 (4) (1992) $428-455$.

[42] B.T. Pentland, Building process theory with narrative: from description to explanation, Acad. Manege. Rev. 24 (4) (1999) $711-724$.

[43] A.M. Pettigrew, Longitudinal field research on change: theory and practice, Organ. Sci. 1 (3) (1990) 280.

[44] K. van den Bosch, De angstreactor: Kalker, kroniek van een eeuwige belofte, Uitgeverij SUN, Amsterdam, 2006.

[45] J.L. De Roos, Kernreactoren, De Technische Uitgeverij. Haarlem, 1959.

[46] Newspaper article. Leeuwarder Courant, Toekomst aan atoom-energie, 13 July 1951, p. 7.

[47] W. Disney, H. Haber, Onze Vriend het Atoom, De Geillustreerde Pers N.V, Amsterdam, 1959, p. 149.

[48] Slideshow. A. Timmermans, Weldaden van het atoom, Fibo-Beeldonderwijs, Zeist. Precise year of production unknown (mid-1950s), http://www.laka.org/ docu/dias/diaprojektie-weldaden.html, last accessed on 20 Oct 2010.

[49] Slideshow. A. Timmermans, Mens en atoom, Fibo-Beeldonderwijs, Zeist. Precise year of production unknown (mid-1950s), http://www.laka.org/docu/dias/ diaprojektie-mens.html, last accessed on 20 Oct 2010.

[50] H.C.M. Edelman, Leven met Atomen: de Atoomkracht in Dienst van Welvaart en Vrede, Meulenhoff, Amsterdam, 1957, p. 17.

[51] ANWB, AutoKampioen, 8 March 1958, p. 396.

[52] J.A.C. Lagaaij, G.P.J. Verbong, Kerntechniek in Nederland 1945-1974, KIvI/Stichting Historie der Techniek, Den Haag/Eindhoven, 1998.

[53] Newspaper article. Leeuwarder Courant, Eerste kernenergiecentrale in ons land in '62 gereed?, 9 July 1957, p. 1.

[54] G.P.J. Verbong, J.A.C. Lagaaij, De Belofte van Kernenergie, in: J.W. Schot, H.W. Lintsen, A. Rip, A.A. Albert de la Bruhèze (Eds.), Techniek in Nederland in de Twintigste Eeuw: Delfstoffen, Energie \& Chemie, Walburg Pers, Zutphen, 2000, pp. 239-256.

[55] Newspaper article. Zierikzeesche Nieuwsbode, Uit het land van de atoombom: konsequenties van de Amerikaanse mentaliteit, 7 August 1945 , p. 24.

[56] Cartoon. L.J. Jordaan, Vrij Nederland, 13 July 1957. http://www.geheugenvannederland.nl/?/nl/items/ATVS01:1130, last accessed on 20 Oct 2010.

[57] W. van Noort, Bevlogen Bewegingen: een Vergelijking van de Anti-kernenergie, Kraak- en Milieubeweging, Uitgeverij Sua, Amsterdam, 1988.

[58] Werkgroep Kernenergie, Kernenergienota, Vereniging Milieudefensie, 1972.

[59] Stichting LAKA, Acties tegen kernenergie 1960-2007, http://www.laka.org/protest/jaar/1960-2007.pdf, 2008, last accessed on 20 Oct 2010, p. 11.

[60] Advertisement. NRC Handelsblad, Leden van de tweede kamer geef ons het voordeel van de twijfel, 31 January 1976 , p. 8.

[61] Cartoon. A. van Dam, Wetenschap \& Samenleving, October 1978.

[62] Poster. A. Schalken, 1974, http://www.geheugenvannederland.nl/?/nl/items/RA01:30051001521779, last accessed on 20 Oct 2010.

[63] Cartoon. A. van Dam, Wetenschap \& Samenleving, October 1978.

[64] Energienota, Tweede Kamer, zitting 1974-1975, 13122 nrs. 1-2, 1974

[65] Bezinningsgroep Energiebeleid, Bezinningsnota Kernenergie, Utrecht, 1974

[66] J. Banning, G. Beernink, A. Fairley, Dodewaard gaat dicht '81: een Fotoverslag, Onderstroom NFK, Nijmegen, 1981 , p. 43.

[67] Poster. Kernenergie leidt tot politiestaat, year of production unknown, http://www.geheugenvannederland.nl/?/nl/items/KDC01:7195591, last accessed on 20 Oct 2010.

[68] Poster. Pacifistisch Socialistische Partij PSP, Stop de atoomstaat, year of production unknown, http://www.geheugenvannederland.nl/?/nl/items/KDC01: 7199223, last accessed on 20 Oct 2010.

[69] H.A. van der Heijden, The Dutch Nuclear Energy Conflict 1973-1989, in: H. Flam (Ed.), States and Anti-nuclear Movements, Edinburgh University Press, Edinburgh, 1994, pp. 101-128.

[70] Newspaper article. Leeuwarder Courant, Ramp in Harrisburg kan Nederlands beleid beïnvloeden, 2 April 1979, p. 3.

[71] Newspaper article. Leeuwarder Courant, Deskundigen menen: menselijk ingrijpen oorzaak Harrisburg, 5 April 1979 , p. 3.

[72] Stuurgroep Maatschappelijke Discussie Energiebeleid, Het eindrapport van de Brede Maatschappelijke Discussie, Leiden: H.E. Stenfert Kroese, Leiden, 1984.

[73] J. Hontelez, Boykotten of er Bovenop Duiken? De Anti-kernenergiebeweging en de BMD, in: L. Wouda, A. Steenbrink (Eds.), Achter de coulissen van de praatshow: geschiedenis en bedoelingen van de BMD, Uitgeverij Macula, Boskoop, 1983, pp. 49-64.

[74] Voorlopige Algemene Energieraad, Advies van de voorlopige algemene energieraad inzake een brede maatschappelijke diskussie over (kern)energie uitgebracht aan de Minister van Economische Zaken d.d. 7 juni 1978, 1978 
[75] S. Schöne, Weg met de BMD en de Technokraten: een Standpunt uit de Anti-kernenergiebeweging, in: L. Wouda, A. Steenbrink (Eds.), Achter de coulissen van de praatshow: geschiedenis en bedoelingen van de BMD, Uitgeverij Macula, Boskoop, 1983, pp. 65-74.

[76] P. de Bok, P.S. Weusten, Achter de Coulissen van de Praatshow, in: L. Wouda, A. Steenbrink (Eds.), Achter de coulissen van de praatshow: geschiedenis en bedoelingen van de BMD, Uitgeverij Macula, Boskoop, 1983, pp. 9-30.

[77] Newspaper article. Leeuwarder Courant, Een zwarte dag, 5 July 1985, p. 1

[78] Newspaper article. Leeuwarder Courant, Tsjernobyl-syndroom, 10 May 1986, p. 19

[79] Cartoon. Peter van Straaten, Het Parool, 9 May 1986. http://www.geheugenvannederland.nl/?/nl/items/PERS01:30051001410494, last accessed on 20 Oct 2010.

[80] G.F. Davis, D. McAdam, W.R. Scott, M.N. Zald, Social Movements and Organization Theory, Cambridge University Press, Cambridge, 2005.

Frank Geels (1971) is professor at SPRU (Science Policy Research Unit), at the University of Sussex. He has worked extensively on socio-technical transitions, codeveloped the multi-level perspective and strategic niche management, and performed a dozen historical case studies to test and elaborate these theories. His work is inter-disciplinary and mobilizes insights from science and technology studies, evolutionary economics, history of technology, (neo)institutional theory and sociology.

Bram Verhees (1977) is a PhD candidate at Eindhoven University of Technology. After acquiring a MSc in technological innovation sciences, he started work on the relationship between socio-technical transitions and culture. This interdisciplinary project is sponsored by the Dutch Knowledge Network for System Innovation and Transitions (KSI) and draws on innovation studies, social movement studies and cultural sociology. Bram is supervised by professors Frank W. Geels and Johan W. Schot. 